\title{
The Role of PPAR Ligands in Controlling Growth-Related Gene Expression and their Interaction with Lipoperoxidation Products
}

\author{
Giuseppina Barrera, ${ }^{1}$ Cristina Toaldo, ${ }^{1}$ Stefania Pizzimenti, ${ }^{1}$ Angelo Cerbone, ${ }^{2}$ \\ Piergiorgio Pettazzoni, ${ }^{1}$ Mario Umberto Dianzani, ${ }^{1}$ and Carlo Ferretti ${ }^{3}$ \\ ${ }^{1}$ Dipartimento di Medicina e Oncologia Sperimentale, Sezione di Patologia Generale, Corso Raffaello 30, 10125 Torino, Italy \\ ${ }^{2}$ Istituto di Ricerche Biomediche "A. Marxer" RBM Merck Serono, Via Ribes 1, 10010 Colleretto Giacosa (Torino), Italy \\ ${ }^{3}$ Dipartimento di Anatomia, Farmacologia e Medicina Legale, sezione di Farmacologia, Via P. Giuria 13, 10125 Torino, Italy
}

Correspondence should be addressed to Giuseppina Barrera, giuseppina.barrera@unito.it

Received 23 April 2008; Accepted 5 June 2008

Recommended by Dipak Panigrahy

Peroxisome proliferators-activated receptors (PPARs) are ligand-activated transcription factors that belong to the nuclear hormone receptor superfamily. The three PPAR isoforms $(\alpha, \gamma$ and $\beta / \delta)$ have been found to play a pleiotropic role in cell fat metabolism. Furthermore, in recent years, evidence has been found regarding the antiproliferative, proapoptotic, and differentiation-promoting activities displayed by PPAR ligands, particularly by PPAR $\gamma$ ligands. PPAR ligands affect the expression of different growth-related genes through both PPAR-dependent and PPAR-independent mechanisms. Moreover, an interaction between PPAR ligands and other molecules which strengthen the effects of PPAR ligands has been described. Here we review the action of PPAR on the control of gene expression with particular regard to the effect of PPAR ligands on the expression of genes involved in the regulation of cellcycle, differentiation, and apoptosis. Moreover, the interaction between PPAR ligands and 4-hydroxynonenal (HNE), the major product of the lipid peroxidation, has been reviewed.

Copyright ( 2008 Giuseppina Barrera et al. This is an open access article distributed under the Creative Commons Attribution License, which permits unrestricted use, distribution, and reproduction in any medium, provided the original work is properly cited.

\section{THE ROLE OF PPAR IN CONTROLLING GENE TRANSCRIPTION}

Peroxisome proliferator-activated receptors (PPARs) are members of the steroid hormone nuclear receptor superfamily which act by altering the transcription of PPARregulated genes by means of a recognition sequence known as a peroxisome proliferation responsive element (PPRE) [1].

The term peroxisome proliferator-activated receptor is derived from early observations in rodent livers that certain industrial compounds could cause an increase in size and number of peroxisomes [2, 3]. Subsequently, these compounds, including fibrates, were found to bind to certain recently identified nuclear receptors [4]; hence, the term "PPAR" arose. PPAR agonists are not known to induce peroxisome proliferation in primates or humans, making the term PPARs archaic as well [5]. At least three subtypes of PPARs have been identified: PPAR $\alpha$, the first isolated from mice liver in 1990 by Issemann and Green [4] and involved in fatty acid oxidation; PPAR $\gamma$, identified by Tontonoz and collaborators as a transcription factor associated with adipocyte determination and differentiation [6]; and $\operatorname{PPAR} \beta / \delta$, ubiquitously expressed and involved in basic cellular functions $[7,8]$. Like other steroid hormone nuclear receptors, PPARs contain several modulating domains: a ligand binding domain (LBD) to which the specific PPAR agonist binds; a transactivating domain (activation function 2, AF 2), which undergoes conformational changes, in response to ligand binding, allowing the heterodimerization with RXR and facilitating recruitment of coactivators and release of corepressor; and finally a DNA-binding domain, which interacts with PPRE [3, 9-11].

PPAR coactivator and corepressor are small accessory molecules that are critical determinants of the transcriptional complex. These accessory molecules include coactivator proteins, like PPAR $\gamma$ coactivator-1 (PGC-1); steroid 


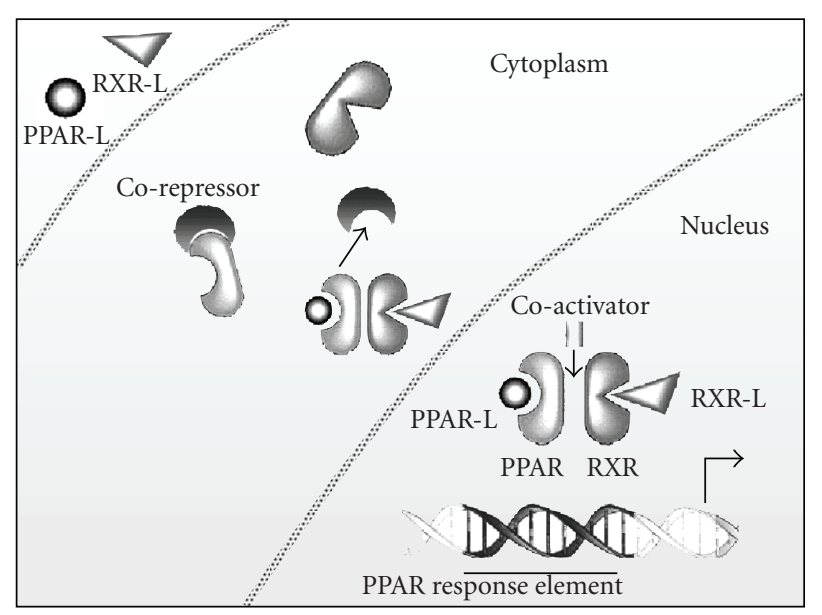

FIGURE 1: Mechanism of PPAR action. PPARs in response to ligand binding in the cytosol, dimerize with RXR, recruit coactivators and release corepressor; in the nucleus a multimolecule complex, formed by PPAR, PPAR ligand, RXR, RXR-ligand, and accessory proteins bind PPRE DNA sequences in the promoters of target genes.

receptor coactivator and CREB (cAMP-response element binding protein)-binding protein, recruited from the activated PPAR; and corepressor proteins, like nuclear receptor corepressor $(\mathrm{N}-\mathrm{CoR})$ and silencing mediator for retinoid and thyroid hormone receptors (SMRTs1), released upon PPAR activation [12, 13]. A multimolecule complex formed by PPAR, PPAR ligand, RXR, RXR-ligand (purportedly 9-cisretinoic acid) and accessory proteins ultimately combine to cause the PPAR response through the binding with PPRE sequences consisting of a direct repeat of the consensus halfsite motif (AGGNCA) spaced by a single nucleotide [14] (Figure 1).

Several genes that are selectively upregulated by a given PPAR isotype have been identified over the years and a majority of these genes is known to play a central role in energy metabolism. Moreover, microarray technology and genome wide identification of PPREs suggest the existence of many other target genes that were not previously known to be regulated by PPAR. The identified PPRE putative sequences on target genes for PPARs are listed in Table 1.

Recent evidence indicates that the PPAR response can result both in gene activation and repression. As far as it regards gene repression, PPAR $\gamma$ was shown to be unable to bind to DNA while it is associated with the corepressor complex. In contrast to PPAR $\gamma$, the interaction between NCoR/SMRT and PPAR $\beta / \delta$ does not impair its DNA binding $[54,55]$. PPAR $\gamma$, after ligand binding, dissociates from the corepressor, and binds to DNA via PPREs. The liberated corepressor protein SMRT interacts with the signal transducer and activator of transcription-3 (STAT3), which inhibits STAT-dependent transactivation [56]. Recent data suggest that PPAR $\gamma$-mediated transrepression may involve stabilization of corepressor recruitment after posttranslational PPAR modification by sumoylation [57].

In macrophages, $\mathrm{PPAR} \beta / \delta$ was shown to function as an activator of the monocyte chemoattractant protein (MCP-1) gene by sequestering a transcriptional repressor, specifically the transcriptional repressor B-cell lymphoma-6 (BCL-6) $[37,58]$. The ligand-induced activation of $\operatorname{PPAR} \beta / \delta$ releases the corepressor BCL- 6 , which is thought to inhibit MCP1 expression. Hence, $\mathrm{PPAR} \beta / \delta$ can function as an intrinsic transcriptional repressor, a mechanism that is also shared by other nuclear receptors such as the thyroid hormone receptor (NR1A1, NR1A2), retinoic acid receptor (NR1B1, NR1B2, NR1B3), Rev-Erb (NR1D1, NR1D2) and COUP-TF (NRT2F3).

The best-documented mechanism by which PPAR $\alpha$ can transrepress non-PPREs containing genes is its ability to physically interact with the p65 subunit of nuclear factor (NF) $-\kappa \mathrm{B}$, which inhibits NF- $\kappa \mathrm{B}$-dependent transactivation [59]. However, PPAR $\alpha$ activators do not inhibit all NF- $\kappa$ Bdriven target genes and their effect is promoter contextdependent. Taken together, data obtained about PPAR transcriptional regulation demonstrated that PPARs can also modulate the transcriptional activity of non-PPRE containing genes via transrepression.

\section{PPAR LIGANDS}

PPAR ligands are a heterogeneous group that includes both endogenous and exogenous ligands [60]. Activating ligands for PPARs are semiselective for the subtype and selectivity depends on ligand concentration and cell type. Endogenous ligands include unsaturated fatty acids that bind all three PPARs, with PPAR $\alpha$ exhibiting the highest activity, while saturated fatty acids are weak PPAR ligands in general [61]. Biological modifications of linoleic acid, linolenic acid, eicosapentanoic acid (EPA), and arachidonic acid originate PPAR $\alpha$ activators [62-64]. Moreover, the oxidized form of EPA, eicosanoids (15-hydroxy-eicosatetranoic acid, HETE and HODEs), and leukotriene B4 has also been reported to be PPAR $\alpha$ activators [62-66].

The natural ligands of PPAR $y$ include several prostanoids such as 15-deoxy-prostaglandin J2 (15d-PG J2) and 15hydroxy-eicosatetranoic acid (HETE), which are metabolites of arachidonic acid [67]. 15d-PG J2 (the most widely used natural ligand for PPAR $\gamma$ ) is gamma-selective at low concentrations but also activates alpha at higher levels $[68,69]$. Like $\operatorname{PPAR} \alpha, \operatorname{PPAR} \beta / \delta$ is activated by long chain fatty acids, including several polyunsaturated fatty acids and eicosanoids [3]. Erucic acid has been reported to be more selective for PPAR $\beta / \delta$ than other PPAR subtypes [70].

Synthetic ligands of PPARs have been demonstrated to possess pharmacological activity. The triglyceridelowering/high-density lipoprotein (HDL)-raising fibrates (gemfibrozil, fenofibrate, clofibrate, ciprofibrate) are PPAR $\alpha$ agonists used clinically to treat dyslipidemia [71, 72]. The insulin-sensitizing thiazolindinedione (TZD) class (troglitazone, pioglitazone and rosiglitazone) is PPAR $\gamma$ activators that are used to treat diabetes mellitus [73, 74]. Several nonsteroidal anti-inflammatory drugs (NSAIDs), in particular indomethacin and ibuprofen, bind to PPAR $\gamma$ and are weak PPAR $\gamma$ agonists at high micromolar concentrations $[75,76]$. 
The first $\mathrm{PPAR} \beta / \delta$-selective agonists (L-165041 and GW501516) were shown to augment HDL-C in diabetic mice as well as in obese rhesus monkeys, in which they decreased elevated levels of triglycerides and insulin $[77,78]$.

\section{THE ROLE OF PPAR LIGANDS IN AFFECTING CELL PROLIFERATION AND DIFFERENTIATION}

Although a direct control of PPAR transcription is limited to a very small number of growth-related genes (see Table 1), the ability of PPAR ligands to inhibit cell growth by inducing cell differentiation or apoptosis has long been demonstrated in several cell lines. In general, the PPAR $\alpha$ and the PPAR $\gamma$ ligands display an inhibitory effect on cell growth, while $\mathrm{PPAR} \beta / \delta$ have different effects, strictly dependent on the cell type. Indeed, in murine colorectal cells, the Apc- $\beta$-catenin tumour-suppressor pathway was shown to repress $\operatorname{PPAR} \beta / \delta$ expression [79]. More recently it was suggested that ligand activation of PPAR $\beta / \delta$ induces expression of cyclooxygenase2 (COX2), which could theoretically promote cell growth and inhibit apoptosis through mechanisms that involve the production of prostaglandins and/or inflammationdependent signalling [80]. However, there are several observations that are inconsistent with the idea that ligands of $\operatorname{PPAR} \beta / \delta$ potentiate cell growth. For example, inhibition of cell growth is observed in a variety of different cells and cell lines cultured in the presence of highly specific $\operatorname{PPAR} \beta / \delta$ ligands including human colonocytes [81], a human lung adenocarcinoma cell line [82], mouse lung fibroblasts [83], rat cardiomyocytes [84], a human keratinocyte cell line [85], normal human keratinocytes [86], and mouse primary keratinocytes [87]. Some evidence about the effects of PPAR ligands on cell differentiation, cell cycle progression, and apoptosis induction is illustrated as follows.

\subsection{Effect of PPAR ligands in differentiation induction}

The first demonstration of PPAR $\gamma$ involvement in adipocyte differentiation was given by Tontonoz et al. (1993) [6]. Subsequently, PPAR $\gamma$ and PPAR $\alpha$ ligands have been demonstrated to induce differentiation alone or in association with other differentiation inducers. It has been demonstrated that clofibrate, a PPAR $\alpha$ ligand, increases the differentiation of HL-60 cells induced by retinoic acid and all-trans retinol [88]. Other $\operatorname{PPAR} \alpha$ activators, including putative endogenous ligands such as fatty acids, induce differentiation and inhibit proliferation in keratinocytes [89]. The PPAR $\alpha$ ligand, ciprofibrate induces differentiation of HL-60 cells and its effect is potentiated by phorbol 12-myristate 13-acetate (TPA) [90]. Benzafibrate induces differentiation of HL-60, U937, and K562 cells [91]. PPAR $\gamma$ ligands induce terminal differentiation of human liposarcoma cells "in vitro" and in patients suffering from advanced liposarcoma [92], and promote terminal differentiation of malignant breast epithelial cells "in vitro" [93]. Our research group demonstrated that both $\operatorname{PPAR} \alpha$ (clofibrate and ciprofibrate) and PPAR $\gamma$ ligands (troglitazone and 15d-PG J2) inhibit growth of HL60 human leukemic cells and induced the onset of monocytic like differentiation [94]. In another leukemic cell line, U937 cells, PPAR $\gamma$ ligands inhibited proliferation but did not induce differentiation (except the higher doses of 15d-PG J2 which induced a poor monocytic differentiation) [94] indicating that the differentiation induction by PPAR ligands is cell-type specific.

Several experimental results indicate that ligand activation of $\operatorname{PPAR} \beta / \delta$ induces terminal differentiation of keratinocytes $[86,87,95,96]$ and it has also been shown that differentiation of breast and colon cancer cell lines is associated with increased expression of $\operatorname{PPAR} \beta / \delta$ [97]. $\mathrm{PPAR} \beta / \delta$ expression also increases following differentiation in human primary macrophages or in monocyte/macrophage cell lines [98]. In addition, activation of $\operatorname{PPAR} \beta / \delta$ using a selective agonist promotes oligodendrocyte differentiation in a mouse cell culture [99].

\subsection{Effect of PPAR ligands on cell cycle progression}

Evidence has been demonstrated that PPAR ligands inhibit cell growth by acting on cell cycle progression. Fibrates, in a dose dependent-manner, significantly alter the cell cycle distribution, mainly leading to G0/G1 phase increase and a G2/M phase reduction in human leukemic cell lines [91]. In HL-60 human leukemic cells, both PPAR $\alpha$ and PPAR $\gamma$ ligands increase the proportion of G0/G1 cells [100]. PPAR $\gamma$, ectopically expressed in nonprecursor fibroblastic cell lines, induces the conversion to adipocytes and induces the expression of p21 and p18, two cyclin/cyclin-dependent kinase (CDK) inhibitors [101]. Troglitazone arrests U937 cells in the G1 phase of the cell cycle [102] and inhibits cyclin D1 expression in MCF7 cells [103]. PPAR $\gamma$ activation induces cell cycle withdrawal of preadipocytes via suppression of the transcriptional activity of E2F/DP DNAbinding complex [104]. E2F activity is regulated by the tumour suppressor retinoblastoma protein $(\mathrm{pRb})$ that, when hypophosphorylated, binds and inactivates the E2F transcription factor [105]. Interestingly, PPAR $\gamma$ ligands inhibit pRb phosphorylation in vascular smooth muscle cells [106108], increasing the amount of hypophosphorylated $\mathrm{pRb}$ able to bind E2F. Others found that troglitazone inhibits the growth of six of nine pancreatic cancer cell lines, by inducing G1 phase cell cycle arrest through the up-regulation of the expression of p21 [109].

Ligand activation of PPAR $\beta / \delta$ with GW0742 prevents cell cycle progression from G1 to $S$ phase and attenuates cell proliferation in N/TERT-1 keratinocyte cells [110].

\subsection{Effect of PPAR ligands on apoptosis induction}

Inhibition of cell proliferation by PPAR ligands is also supported by their effect on apoptosis induction. PPAR $\gamma$ ligands seem to be more effective than PPAR $\alpha$ in inducing apoptosis, since its proapototic activity has been demonstrated in a wide variety of experimental cancer models [111]. PPAR $\gamma$ ligands have been reported to reduce levels of FLICEinhibitory protein (FLIP), and apoptosis-suppressing protein that blocks early events in TRAIL/TNF (Tumor necrosis factor-related apoptosis inducing ligand/Tumor necrosis factor) family death receptor signalling [112]. 15d-PG J2 and 
TABLE 1

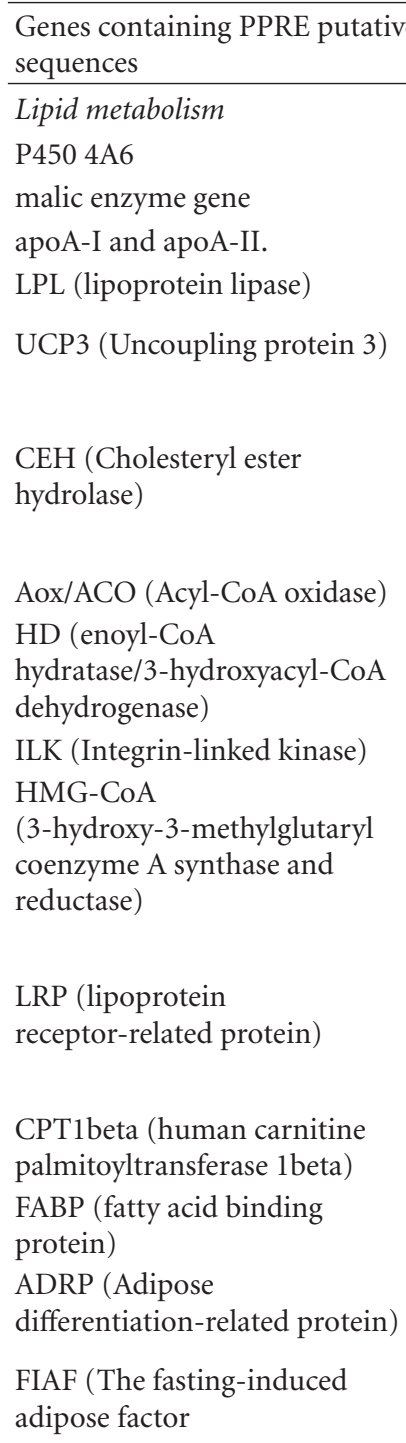

Carbohydrate metabolism

betaGK (beta-cell-specific

glucokinase)

dehydrogenase)

UGDH (UDP-glucose

dehydrogenase)

PDK (Pyruvate dehydrogenase kinase)

SHP (Small heterodimer partner)
GPDH (Glycerol 3-phosphate

Function of gene

Ref.

Omega oxidation of fatty acids

Fatty acid synthesis

Components of HDL

Fatty acid transport and

thermogenesis

Hydrolysis of stored cholesterol esters in macrophage foam cells and release of free cholesterol for high-density lipoprotein-mediated efflux

Beta-oxidation in peroxisome

Beta oxidation in perixisome

Integrin-mediated signaling

Cholesterol biosynthesis

Lipoprotein metabolism, neurological function, tissue remodelling, protease complex

clearance, cell signal

transduction

Fatty acid mitochondrial

beta-oxidation

Lipid transport (solubilization of long-chain fatty acids)

Maintenance of lipid stores in non-adipocytes

Circulating lipoprotein lipase inhibitor secreted from adipose tissue

Glucose-sensing apparatus in pancreatic beta-cells

NAD-dependent enzyme that catalyzes the oxidation of sn-glycerol 3-phosphate to dihydroxyacetone phosphate. It restores NAD+.

Biosynthesis of complex carbohydrates and detoxification of toxic compounds in the liver

Modulation of pyruvate dehydrogenase complex activity

Bile acid-dependent down regulation of gluconeogenic gene expression in liver

Thromboxane receptor (TP) beta transcription

Prm3 (thromboxane receptor (TP) beta promoter)

IL-1 receptor signaling blockage

IL-1ra (Interleukin-1 receptor antagonist) 
TABle 1: Continued.

\begin{tabular}{|c|c|c|}
\hline $\begin{array}{l}\text { Genes containing PPRE putative } \\
\text { sequences }\end{array}$ & Function of gene & Ref. \\
\hline CD36 (scavenger receptor) & Scavenger receptor & {$[36]$} \\
\hline $\begin{array}{l}\text { sPLA2-IIA (Group IIA secretory } \\
\text { phospholipase A2) }\end{array}$ & Proinflammatory effect & {$[37]$} \\
\hline $\begin{array}{l}\text { AhR (Aromatic hydrocarbon } \\
\text { receptor) }\end{array}$ & Proinflammatory effect & {$[38]$} \\
\hline \multicolumn{3}{|l|}{$\begin{array}{l}\text { Growth factors and cell cycle } \\
\text { regulators }\end{array}$} \\
\hline $\begin{array}{l}\text { SSAT (spermidine/spermine } \\
\text { N1-acetyltransferase) }\end{array}$ & Polyamine catabolism & {$[39]$} \\
\hline GOS2 (GO/G1 switch gene 2) & Cell cycle regulation & {$[40]$} \\
\hline $\begin{array}{l}\text { VEGF (Vascular endothelial } \\
\text { growth factor) }\end{array}$ & Vasculogenesis & {$[41]$} \\
\hline $\begin{array}{l}\text { IGFBP-1 (Insulin-like growth } \\
\text { factor-binding protein 1) }\end{array}$ & $\begin{array}{l}\text { Binding protein of insulin-like } \\
\text { growth factor (IGF)-I and } \\
\text { IGF-II. Biomarker for metabolic } \\
\text { and hyperproliferative diseases }\end{array}$ & {$[42]$} \\
\hline \multicolumn{3}{|l|}{ Detoxification and redox enzymes } \\
\hline $\begin{array}{l}\text { CYP1A1 (Cytochrome P450 } \\
\text { 1A1) }\end{array}$ & $\begin{array}{l}\text { Degradation of endobiotics and } \\
\text { the bioactivation of numerous } \\
\text { environmental procarcinogens }\end{array}$ & {$[43]$} \\
\hline $\begin{array}{l}\text { GST (glutathione S-transferase } \\
\text { gene) }\end{array}$ & Antioxidant function & {$[44]$} \\
\hline POX (Proline oxidase) & Redox enzyme & {$[45]$} \\
\hline $\begin{array}{l}\text { VDUP-1 (Vitamin } \\
\text { D-upregulated protein-1) }\end{array}$ & $\begin{array}{l}\text { Inhibition of thioredoxin-1 } \\
\text { which plays a role in the } \\
\text { regulation of cellular redox } \\
\text { balance (Cellular redox balance) }\end{array}$ & {$[46]$} \\
\hline \multicolumn{3}{|l|}{ Others } \\
\hline $\begin{array}{l}\text { BCM (Beta-carotene } \\
15,15^{\prime} \text {-monooxygenase) }\end{array}$ & Vitamin A biosynthesis & {$[47]$} \\
\hline $\begin{array}{l}\text { I-BABP (Ileal bile acid-binding } \\
\text { protein) }\end{array}$ & $\begin{array}{l}\text { Enterohepatic circulation of bile } \\
\text { acids }\end{array}$ & {$[48]$} \\
\hline PCLN-1 (paracellin-1) & $\begin{array}{l}\text { Tight-junction protein, } \\
\text { exclusively, in the kidney }\end{array}$ & {$[49]$} \\
\hline $\begin{array}{l}\text { BACE1(Beta-site amyloid } \\
\text { precursor protein cleaving } \\
\text { enzyme) }\end{array}$ & $\begin{array}{l}\text { Central causal role in } \\
\text { Alzheimer's disease }\end{array}$ & {$[50]$} \\
\hline nephrin promoter & Nephrin synthesis & {$[51]$} \\
\hline $\begin{array}{l}\text { CIDEA (Cell death-inducing } \\
\text { DNA fragmentation factor } \\
\text { alpha-like effector A) }\end{array}$ & Proapoptotic protein & {$[52]$} \\
\hline TFF2 (Trefoil factor family 2) & $\begin{array}{l}\text { Defense and repair of gastric } \\
\text { mucosa }\end{array}$ & {$[53]$} \\
\hline
\end{tabular}

troglitazone suppress DNA synthesis and induce apoptosis in a dose-dependent way in HT-29 colon cancer cells, whereas ligands for PPAR $\alpha$ and $\beta / \delta$ had no significant effect [113]. Troglitazone inhibited growth of liver cancer cells PLC/PRF/5, HepG2 and HuH-7, by inducing apoptosis through caspase-3 activation [114]. In breast cancer cells, both troglitazone and 15d-PG J2 induce apoptosis [115, 116]. Kondo et al. have shown that the 15d-PG J2-induced accumulation of p53 results in the activation of a deathinducing caspase cascade mediated by Fas and the Fas ligand in neurons [117]. Activation of PPAR $\gamma$ by troglitazone or 15d-PG J2 inhibits cell growth via apoptosis and blocks cell cycle in human colorectal cancer [118]. However, in some cell models, both PPAR $\alpha$ and PPAR $\gamma$ displayed proapoptotic activity, as it has been demonstrated in the HL-60 cell line [100] and in the lymphoblastic leukaemia cell line [119]. In 
keratinocytes [120], ovarian cancer cells [121] and in human hepatoma cell line SK-HEP-1 [122], PPAR $\alpha$ ligands have been reported to induce apoptosis.

Colon cancer cell lines cultured in the presence of the PPAR $\beta / \delta$ ligand GW501516 exhibit inhibited levels of apoptosis $[123,124]$. It has been postulated that apoptosis is inhibited by $\mathrm{PPAR} \beta / \delta$-dependent downregulation of the tumour suppressor phosphatase and tensin homologue deleted on chromosome ten (PTEN) and upregulation of the 3-phosphoinositide-dependent kinase-1 (PDK1) and integrin-linked kinase-1 (ILK1) [22]. The net effect of this change in activity would have increased phosphorylation of protein kinase B (Akt) and inhibition of apoptosis; and these changes were shown in cultured primary keratinocytes [22]. In mouse keratinocytes, $\operatorname{PPAR} \beta / \delta$ inhibits proliferation and promotes cell survival and migration [96, 125, 126]. In contrast with these data, prostacyclin $\left(\mathrm{PGI}_{2}\right)$ was shown to promote apoptosis in a kidney cell line, most probably through PPAR $\beta / \delta$ activation [127].

\section{THE ROLE OF PPAR LIGANDS IN THE CONTROL OF GROWTH-RELATED GENE EXPRESSION}

The effect of PPAR ligands in the expression of growth regulatory genes has been in part illustrated in the previous section. Results obtained until now do not allow the identification of a precise signalling pathway and the PPAR target genes that mediate the antiproliferative effects remain elusive, as genomic responses to PPAR $\gamma$ activation in cancer cells are highly complicated [128]. PPAR $\gamma$ ligands seem to be more effective than PPAR $\alpha$ ligands in inhibiting cell growth, thus the majority of data about the gene expression following treatment with PPAR ligands is obtained in PPAR $y$ ligand-treated cells. Recently, some evidence has been found for $\mathrm{PPAR} \beta / \delta$ and its ligands in regulating gene expression. However, the number of growth-regulatory genes, affected by specific $\mathrm{PPAR} \beta / \delta$ ligands, is limited and comprises growth-inducing genes such as COX2 [80], and Akt, via transcriptional upregulation of integrin linked kinase (ILK) and 3-phosphoinositide-dependent kinase-1 (PDK1) [22] and the decrease in the level of ERK phosphorylation [110].

Reported causal mechanisms for PPAR $y$ growth inhibitory effects include attenuated expression of protein phosphatase $2 \mathrm{~A}$ and subsequent inhibition of E2F/DP DNA binding [129], the inhibition of cyclins D1 and E, inflammatory cytokines and transcription factors expression [130] and increased expression of an array of gene products linked to growth regulation and cell maturation [128]. Moreover, our and other research groups have demonstrated that the reduction of cell growth by PPAR ligands is accompanied by the downregulation of the c-myc gene in myeloid leukaemia cells [131] and in colon cancer cells $[132,133]$. In the HL-60 cell line, both PPAR $\alpha$ (ciprofibrate and clofibrate) and PPAR $\gamma$ (troglitazone and 15d-PG J2) ligands inhibit c-myb and cyclin D2 expressions [100]. In prostate cancer cells PPAR $y$ ligands omega- 6 fatty acids and ciglitazone down-regulated (1-2-fold) beta-catenin and c-myc expression and the selective PPAR $y$ antagonist GW9662 abolished the effect of those ligands, demonstrating a PPAR-dependent mechanism. 15-d PG J2 inhibits N-myc expression in neuroblastoma cells [134] while it does not decrease c-myc expression in vascular smooth muscle cells [135].

The major part of the genes of which expression is modulated by PPAR $\gamma$ ligands does not contain PPRE putative sequences in their promoter regions. Besides downregulation of c-myc, c-myb, and cyclin D2 genes, previously reported, an array ofnon-PPAR $\gamma$ targets has been implicated in the antitumor activities of troglitazone and/or ciglitazone in several cell systems. These targets include intracellular $\mathrm{Ca}^{2+}$ stores [136], phosphorylating activation of extracellular signal-regulated kinases [137, 138], c-JunN-terminal protein kinase, and p38 [139], upregulationof early growth response1 [140], the CDK inhibitors p27 [141] and p21 [142], the tumor suppressor protein p53 and the p53-responsive stress protein Gadd45 [135], and altered expression of Bcell leukemia/lymphoma 2 (Bcl-2)family members [139]. However, some of these targets appear to be cell-type specific due to differences insignalling pathways regulating cell growth and survival in differentcell systems.

Recent findings demonstrate that part of the above mentioned growth-regulatory genes are affected by PPAR ligands, mostly by PPAR $\gamma$ through a PPAR-independent mechanism. The most important evidence of PPAR-independent effects displayed by PPAR ligands is illustrated in Table 2 .

\section{THE PRODUCTS OF LIPID PEROXIDATION IN THE CONTROL OF GROWTH-RELATED GENE EXPRESSION}

Reactive intermediates produced during oxidative stressful conditions cause the oxidation of polyunsaturated fatty acids such as arachidonic, linolenic, and linoleic acids of membrane lipid bilayers or low-density lipoprotein [156] leading eventually to the formation of several aldehydes. Among the products of oxidative breakdown of polyunsaturated fatty acid, 4-hydroxy-2,3-trans-alkenals have been proposed as ultimate messengers of lipid peroxidationinduced injury, because they can diffuse from the site where they are produced and can reach different intracellular and extracellular targets [157-159]. 4-hydroxynonenal (HNE), the aldehyde most represented in the 4-hydroxy-2,3-transalkenal class, has long been investigated, since, at concentrations near to those "physiologically" found in normal cells and plasma, it modulates cellular functions, gene expression and biochemical pathways, without cytotoxic effects [160]. For this reason, HNE has been proposed by several authors as an intracellular signalling mediator, rather than a toxic product of lipid peroxidation $[159,161]$. Previous results demonstrated the antiproliferative and differentiative effects of HNE in leukemic cells $[162,163]$ and the antiproliferative and proapoptotic effects in a number of different cell models $[164,165]$. Deeper investigations into HL-60 cells showed that the proliferation block occurred at the level of the G0/G1 stage of the cell cycle [163]. Further experiments showed that the HNE effects depend on the inhibition of the cyclin expression, and especially of cyclins D2, D1, and A [166]. The reduction of cyclin expression can result in a reduced 
TABLE 2: PPAR-independent effects on tumor-related genes.

\begin{tabular}{l} 
PPARs ligand \\
\hline PPAR y ligands \\
Troglitazone in LNCaP \\
prostate cancer cells
\end{tabular}

prostate cancer cells

Troglitazone in mice

Troglitazone and ciglitazone in MCF-7 breast cancer

Ciglitazone in HT1080

human fibrosarcoma

Troglitazone and

15-deoxy-prostaglandin $\mathrm{J} 2$

(15dPGJ2) in prostate and bladder cancer cells

Troglitazone in B cell acute lymphoblastic leukemia cell lines

Thiazolidinediones (TZD) in human breast cancer

Troglitazone in mouse skin keratinocytes

Thiazolidinediones (TGZ) in human colon cancer cells HTC-116

15-deoxy-prostaglandin J2

(15dPGJ2) in colon

carcinoma cells

15-deoxy-prostaglandin J2 (15dPGJ2) induces apoptosis in human B lymphocytes

15-deoxy-prostaglandin J2 (15dPGJ2) in Jurkat human leukemic cells and PC3 human prostate cancer cells

\section{PPARa ligands}

DEHP in mice

WY14,643 in activated splenocytes isolated from C57BL/6 mice

$P P A R \beta / \delta$ ligands

GW0742 in PPAR $\beta$-null mouse model
PPAR-independent effect

Experimental strategies

Ref.

Androgen receptor (AR)

suppression by facilitating the

ubiquitin-dependent proteasomal

degradation of the transcriptional

factor Sp-1

Rapidly AMP-activated protein

kinase (AMPK) activation through

a yet undefined

PPAR- $\gamma$-independent mechanism, leading to the suppression of

insulin-like growth factor-I

tumor-promoting activity (IGF-1)

Repression of cyclin D1 expression, though a post transcriptional

mechanism, via

proteasome-facilitated proteolysis

Increase of MMP-2 expression

through ROS production and ERK activation

STG28, a PPAR $\gamma$-inactive

analogue of troglitazone.

Expression of a

dominant-negative AMPK

Troglitazone induces G0/G1 growth arrest and PGJ2 induces apoptosis

PPAR $\gamma$ antagonist GW9662

Apoptosis and cell growth

inhibition associated with G1 cell

cycle arrest

PPAR antagonists

Inhibition of Cyclin D3 expression by decreasing cyclin mRNA levels and by inducing its proteasomal degradation

Inhibition of cyclin D1 expression

Egr-1 promoter activity increase

COX2 and VEGF inhibition via

AP-1 activity repression

Apoptosis through the induction of ROS and depletion of glutathione

Apoptosis by increasing the mRNA stability of death Receptor 5 (DR5), a specific receptor for tumor-necrosis factor-related apoptosis-inducing ligand (TRAIL)

A dominant negative mutant of PPAR $\gamma$

PPAR $\gamma$ antagonist GW9662 and dominant Dominant negative $\operatorname{PPAR} \gamma$.

Different PPAR $\gamma$ ligands

Dominant negative form of $\operatorname{PPAR} \gamma$ and a PPAR $\gamma$ antagonist

Dominant negative form of $\operatorname{PPAR} \gamma$ and a PPAR $\gamma$ antagonist

PPAR $\gamma$ antagonist GW9662

Induction of hepatic tumorigenesis

Wild-type and PPAR $\alpha$-null mice in comparison

Apoptosis

Wild-type and PPAR $\alpha$-null mice in comparison

Induction of keratinocyte terminal differentiation and inhibition of keratinocyte proliferation
$\operatorname{PPAR} \delta$-null mice

[86] 
activity of cyclin/CDK complexes which principally regulate the phosphorylation of the $\mathrm{pRb}$. In highly proliferating tumour cells, pRb is constantly in the hyperphosphorylated status. When hyperphosphorylated, $\mathrm{pRB}$ cannot bind to E2F transcription factors that can promote the G1/S cell cycle phase passage. After HNE treatment, $\mathrm{pRb}$ remains hypophosphorylated, and E2F remains bound to $\mathrm{pRb}$ [167]. HNE not only reduces the phosphorylation of $\mathrm{pRb}$, but also decreases the amount of "free" E2F bound to the P2 c-myc promoter. These effects can explain the blocking of c-myc expression demonstrated in HNE-treated cells.

The hypophosphorylation of $\mathrm{pRb}$ proteins may depend on the inhibition of cyclin expression, however, this effect may also be related to the increase of the expression of p21, an inhibitor of the cyclin/CDK complexes, induced by HNE treatment [167]. Another effect of HNE, also important for cell multiplication, is that displayed on telomerase activity and hTERT expression. The activity of telomerase and the expression of its catalytic subunit hTERT, were inhibited by HNE in three different human leukemic cell lines, HL-60, U937 and ML-1 [168]. The binding studies of E-box in the hTERT promoter demonstrated that in HNE-treated HL-60 cells there is a decrease in Myc binding complexes and an increase in Mad-1 binding complexes which could contribute to the switch from c-Myc/Max to Mad1/Max with repressor activity of the transcription.

HNE is able to induce p53 expression in ML-1 cells, according to previous results demonstrating the induction of p53 expression by HNE in the SK-N-BE human neuroblastoma cell line [165]. Moreover, in SK-N-BE cells apoptosis was substantially increased even with $1 \mu \mathrm{M}$ HNE. At the same time, the expression of the p53 family members, p63 and p73, was strongly increased as well as the expression of the cyclin/CDK inhibitor p21 and the proapoptotic bax gene. Since p21 and bax are the two main targets for the transcription factor $\mathrm{p} 53$, these results indicate that HNE, by acting on p53 gene expression, can regulate the p53 target genes.

\section{INTERACTION BETWEEN PPAR LIGANDS AND LIPOPEROXIDATION PRODUCTS}

The relationship between oxidative stress-related molecules and PPAR activation has not yet been elucidated. Based upon their capacity to elicit cellular responses to a variety of stimuli, PPARs may represent a class of molecules which allow the biochemical adaptation to a diverse range of internal and external signals. These include oxidised LDL [169] and inflammatory agents as well as 15d-PG J2 [170] and leukotriene B4 [65]. However, other molecules generated during inflammation may be involved. In the cultured mesangial cells, PPAR $\gamma$ is activated by various oxidative stress-related molecules such as TPA, TNF alpha, and $\mathrm{H}_{2} \mathrm{O}_{2}$ [171]. The physiological ligand of PPAR $\gamma, 15 \mathrm{~d}-\mathrm{PG} \mathrm{J} 2$, is a potential inducer of intracellular oxidative stress that mediates the cytotoxic effects in human neuroblastoma cells [172]. On the other hand, the activation of PPAR $\alpha$ leads to increased oxidative stress in liver cells [173]. On the basis of this link between oxidative stress and PPAR activation and between oxidative stress and lipoperoxidation induction, our research group investigated, for the first time, the interaction between the major lipoperoxidation product, HNE, and PPAR activation in HL-60 and U937 human leukemic cells [94]. We demonstrated that HNE increases the monocytic differentiation induced by the PPAR $\alpha$ ligand ciprofibrate, and PPAR $\gamma$ ligands, troglitazone and 15d-PG J2, in HL-60 cells. Whereas, neither $\operatorname{PPAR} \alpha$ nor $\operatorname{PPAR} \gamma$ ligands induce U937 differentiation. Moreover, in this cell line, only PPAR $\gamma$ ligands reduce cell growth. HNE also significantly inhibits cell growth when given alone, and strengthens the growth inhibitory effect of a low dose of PPAR $\gamma$ ligands. HNE promotes at the same time a great increase in the expression of PPAR $y$ in both HL-60 and U937 cells, without any modification of the PPAR $\alpha$ expression. These results suggest a synergistic effect of HNE and PPAR $\gamma$ ligands in blocking cell growth and in promoting the differentiation in HL-60 cells.

More recently, we analysed the effects of PPAR $\gamma$ ligands (rosiglitazone and 15d-PG J2) and HNE, alone or in association, on proliferation, apoptosis, differentiation, and growthrelated and apoptosis-related gene expressions in $\mathrm{CaCo}-2$, colon cancer cells. Results obtained indicate that, in this cell line, PPAR $\gamma$ ligands and HNE inhibited cell growth and induced differentiation or apoptosis by different signalling pathways. The common feature consisted of the inhibition of c-myc expression, whereas the apoptosis was induced by 15d-PG J2 and HNE and, to a minor extent, by rosiglitazone and the differentiation was induced by rosiglitazone and by 15d-PG J2, but not by HNE. Moreover, HNE induced p21 expression, while PPAR $\gamma$ ligands did not. Bax expression was increased by HNE and 15d-PG J2, but not by rosiglitazone. HNE did not induce an increase of PPAR $\gamma$ expression and did not display synergism or antagonism towards PPAR $\gamma$ ligands.

These various results, obtained in different cell models, strongly demonstrate that the gene expression control exerted by PPAR ligands is dependent on the cell type examined.

An interaction between HNE and PPAR $\gamma$ has also been demonstrated by Muzio et al. (2006) [174]. These authors found that arachidonic acid induces suppression of human lung tumor A549 cell growth, increases lipid peroxidation and decreases aldehyde dehydrogenase 3A1 ALDH3A1, which may determine an accumulation of endogenous HNE. These phenomena are associated with the increased expression of PPAR $\gamma$, suggesting a relationship between endogenous HNE levels and PPAR $\gamma$ expression. Moreover, it has been postulated that HNE can represent an endogenous modulator of PPAR $\beta / \delta$ activity, since HNE is an endogenous ligand for $\operatorname{PPAR} \beta / \delta$ and activates $\operatorname{PPAR} \beta / \delta$ target genes [175]. This datum suggest that the binding between HNE and $\mathrm{PPAR} \beta / \delta$ can modulate $\mathrm{PPAR} \beta / \delta$ activity in all cell types, since $\mathrm{PPAR} \beta / \delta$ is ubiquitously expressed.

The different interactions between HNE and PPAR are summarized in Figure 2.

These findings represent an intriguing suggestion about the role played by the lipoperoxidation products in controlling cellular PPAR-dependent responses, not only regarding cell proliferation control but also in the regulation of 


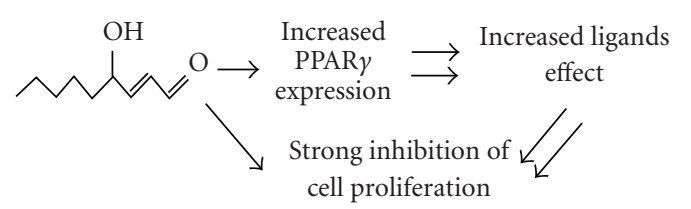

(a)

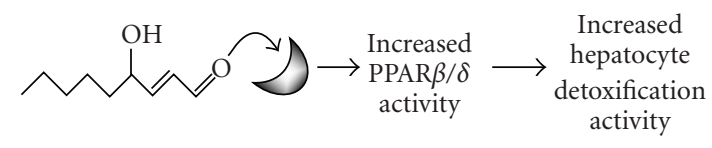

(b)

Figure 2: Different interactions between HNE and PPAR. (a) HNE increases PPAR $y$ expression in leukemic cell lines; (b) HNE binds and activates $\operatorname{PPAR} \beta / \delta$.

different metabolic pathways, and indicate that the interaction between oxidative stress products and PPAR activity represents a new research field in expansion.

\section{REFERENCES}

[1] C. N. A. Palmer, M.-H. Hsu, K. J. Griffin, and E. F. Johnson, "Novel sequence determinants in peroxisome proliferator signaling," The Journal of Biological Chemistry, vol. 270, no. 27, pp. 16114-16121, 1995.

[2] R. Hess, W. Stäubli, and W. Riess, "Nature of the hepatomegalic effect produced by ethyl-chlorophenoxy-isobutyrate in the rat," Nature, vol. 208, no. 5013, pp. 856-858, 1965.

[3] T. M. Willson, P. J. Brown, D. D. Sternbach, and B. R. Henke, "The PPARs: from orphan receptors to drug discovery," Journal of Medicinal Chemistry, vol. 43, no. 4, pp. 527-550, 2000.

[4] I. Issemann and S. Green, "Activation of a member of the steroid hormone receptor superfamily by peroxisome proliferators," Nature, vol. 347, no. 6294, pp. 645-650, 1990.

[5] R. C. Cattley, J. DeLuca, C. Elcombe, et al., "Do peroxisome proliferating compounds pose a hepatocarcinogenic hazard to humans?" Regulatory Toxicology and Pharmacology, vol. 27, no. 1, pp. 47-60, 1998.

[6] P. Tontonoz, J. B. Kim, R. A. Graves, and B. M. Spiegelman, "ADD1: a novel helix-loop-helix transcription factor associated with adipocyte determination and differentiation," Molecular and Cellular Biology, vol. 13, no. 8, pp. 4753-4759, 1993.

[7] P. Escher, O. Braissant, S. Basu-Modak, L. Michalik, W. Wahli, and B. Desvergne, "Rat PPARs: quantitative analysis in adult rat tissues and regulation in fasting and refeeding," Endocrinology, vol. 142, no. 10, pp. 4195-4202, 2001.

[8] G. D. Barish, V. A. Narkar, and R. M. Evans, "PPAR $\delta$ : a dagger in the heart of the metabolic syndrome," The Journal of Clinical Investigation, vol. 116, no. 3, pp. 590-597, 2006.

[9] A. I. Shulman and D. J. Mangelsdorf, "Retinoid X receptor heterodimers in the metabolic syndrome," The New England Journal of Medicine, vol. 353, no. 6, pp. 604-615, 2005.

[10] S. A. Kliewer, H. E. Xu, M. H. Lambert, and T. M. Willson, "Peroxisome proliferator-activated receptors: from genes to physiology," Recent Progress in Hormone Research, vol. 56, pp. 239-265, 2001.
[11] C. K. Glass and S. Ogawa, "Combinatorial roles of nuclear receptors in inflammation and immunity," Nature Reviews Immunology, vol. 6, no. 1, pp. 44-55, 2006.

[12] W. Yang, C. Rachez, and L. P. Freedman, "Discrete roles for peroxisome proliferator-activated receptor $\gamma$ and retinoid $\mathrm{X}$ receptor in recruiting nuclear receptor coactivators," Molecular and Cellular Biology, vol. 20, no. 21, pp. 80088017, 2000.

[13] P. Puigserver and B. M. Spiegelman, "Peroxisome proliferator-activated receptor- $\gamma$ coactivator $1 \alpha$ (PGC- $1 \alpha)$ : transcriptional coactivator and metabolic regulator," Endocrine Reviews, vol. 24, no. 1, pp. 78-90, 2003.

[14] S. A. Kliewer, K. Umesono, D. J. Noonan, R. A. Heyman, and R. M. Evans, "Convergence of 9-cis retinoic acid and peroxisome proliferator signalling pathways through heterodimer formation of their receptors," Nature, vol. 358, no. 6389, pp. 771-774, 1992.

[15] C. N. A. Palmer, M.-H. Hsu, A. S. Muerhoff, K. J. Griffin, and E. F. Johnson, "Interaction of the peroxisome proliferatoractivated receptor $\alpha$ with the retinoid X receptor $\alpha$ unmasks a cryptic peroxisome proliferator response element that overlaps an ARP-1-binding site in the CYP4A6 promoter," The Journal of Biological Chemistry, vol. 269, no. 27, pp. 18083-18089, 1994.

[16] H. Castelein, T. Gulick, P. E. Declercq, G. P. Mannaerts, D. D. Moore, and M. I. Baes, "The peroxisome proliferator activated receptor regulates malic enzyme gene expression," The Journal of Biological Chemistry, vol. 269, no. 43, pp. 26754-26758, 1994.

[17] K. Schoonjans, B. Staels, and J. Auwerx, "Role of the peroxisome proliferator-activated receptor (PPAR) in mediating the effects of fibrates and fatty acids on gene expression," Journal of Lipid Research, vol. 37, no. 5, pp. 907-925, 1996.

[18] K. Schoonjans, J. Peinado-Onsurbe, A.-M. Lefebvre, et al., "PPAR $\alpha$ and PPAR $\gamma$ activators direct a distinct tissue-specific transcriptional response via a PPRE in the lipoprotein lipase gene," The EMBO Journal, vol. 15, no. 19, pp. 5336-5348, 1996.

[19] A. Acín, M. Rodriguez, H. Rique, E. Canet, J. A. Boutin, and J.-P. Galizzi, "Cloning and characterization of the 5 ' flanking region of the human uncoupling protein 3 (UCP3) gene," Biochemical and Biophysical Research Communications, vol. 258, no. 2, pp. 278-283, 1999.

[20] S. Ghosh and R. Natarajan, "Cloning of the human cholesteryl ester hydrolase promoter: identification of functional peroxisomal proliferator-activated receptor responsive elements," Biochemical and Biophysical Research Communications, vol. 284, no. 4, pp. 1065-1070, 2001.

[21] A. Kassam, J. P. Capone, and R. A. Rachubinski, “The short heterodimer partner receptor differentially modulates peroxisome proliferator-activated receptor $\alpha$-mediated transcription from the peroxisome proliferator-response elements of the genes encoding the peroxisomal $\beta$-oxidation enzymes acyl-CoA oxidase and hydratase-dehydrogenase," Molecular and Cellular Endocrinology, vol. 176, no. 1-2, pp. 49-56, 2001.

[22] N. Di-Poï, N. S. Tan, L. Michalik, W. Wahli, and B. Desvergne, "Antiapoptotic role of PPAR $\beta$ in keratinocytes via transcriptional control of the Akt1 signaling pathway," Molecular Cell, vol. 10, no. 4, pp. 721-733, 2002.

[23] K. T. Iida, Y. Kawakami, H. Suzuki, et al., "PPAR $y$ ligands, troglitazone and pioglitazone, up-regulate expression of HMG-CoA synthase and HMG-CoA reductase gene in THP1 macrophages," FEBS Letters, vol. 520, no. 1-3, pp. 177-181, 2002. 
[24] A. Gauthier, G. Vassiliou, F. Benoist, and R. McPherson, "Adipocyte low density lipoprotein receptor-related protein gene expression and function is regulated by peroxisome proliferator-activated receptor $\gamma$," The Journal of Biological Chemistry, vol. 278, no. 14, pp. 11945-11953, 2003.

[25] Á. Baldán, J. Relat, P. F. Marrero, and D. Haro, "Functional interaction between peroxisome proliferator-activated receptors- $\alpha$ and Mef-2C on human carnitine palmitoyltransferase $1 \beta(\mathrm{CPT} 1 \beta)$ gene activation," Nucleic Acids Research, vol. 32, no. 16, pp. 4742-4749, 2004.

[26] C. Brouillette, Y. Bossé, L. Pérusse, D. Gaudet, and M.-C. Vohl, "Effect of liver fatty acid binding protein (FABP) T94A missense mutation on plasma lipoprotein responsiveness to treatment with fenofibrate," Journal of Human Genetics, vol. 49, no. 8, pp. 424-432, 2004.

[27] P. Targett-Adams, M. J. McElwee, E. Ehrenborg, M. C. Gustafsson, C. N. Palmer, and J. McLauchlan, "A PPAR response element regulates transcription of the gene for human adipose differentiation-related protein," Biochimica et Biophysica Acta, vol. 1728, no. 1-2, pp. 95-104, 2005.

[28] S. Mandard, F. Zandbergen, N. S. Tan, et al., "The direct peroxisome proliferator-activated receptor target fastinginduced adipose factor (FIAF/PGAR/ANGPTL4) is present in blood plasma as a truncated protein that is increased by fenofibrate treatment," The Journal of Biological Chemistry, vol. 279, no. 33, pp. 34411-34420, 2004.

[29] H. Kim, J.-Y. Cha, S.-Y. Kim, et al., "Peroxisomal proliferatoractivated receptor- $\gamma$ upregulates glucokinase gene expression in $\beta$-cells," Diabetes, vol. 51, no. 3, pp. 676-685, 2002.

[30] D. Patsouris, S. Mandard, P. J. Voshol, et al., "PPAR $\alpha$ governs glycerol metabolism," The Journal of Clinical Investigation, vol. 114, no. 1, pp. 94-103, 2004.

[31] J. Vatsyayan, C.-T. Lin, H.-L. Peng, and H.-Y. Chang, "Identification of a cis-acting element responsible for negative regulation of the human UDP-glucose dehydrogenase gene expression," Bioscience, Biotechnology and Biochemistry, vol. 70, no. 2, pp. 401-410, 2006.

[32] T. Degenhardt, A. Saramäki, M. Malinen, et al., "Three members of the human pyruvate dehydrogenase kinase gene family are direct targets of the peroxisome proliferatoractivated receptor $\beta / \delta$," Journal of Molecular Biology, vol. 372, no. 2, pp. 341-355, 2007.

[33] H. Kim, Y.-K. Koh, T.-H. Kim, et al., "Transcriptional activation of SHP by PPAR- $\gamma$ in liver," Biochemical and Biophysical Research Communications, vol. 360, no. 2, pp. 301-306, 2007.

[34] A. T. Coyle, M. B. O'Keeffe, and B. T. Kinsella, "15-deoxy $\Delta^{12,14}$-prostaglandin $\mathrm{J}_{2}$ suppresses transcription by promoter 3 of the human thromboxane $A_{2}$ receptor gene through peroxisome proliferator-activated receptor $\gamma$ in human erythroleukemia cells," FEBS Journal, vol. 272, no. 18, pp. 4754 $4773,2005$.

[35] R. Stienstra, S. Mandard, N. S. Tan, et al., "The Interleukin-1 receptor antagonist is a direct target gene of PPAR $\alpha$ in liver," Journal of Hepatology, vol. 46, no. 5, pp. 869-877, 2007.

[36] I. Jedidi, M. Couturier, P. Thérond, et al., "Cholesteryl ester hydroperoxides increase macrophage CD36 gene expression via PPAR $\alpha$," Biochemical and Biophysical Research Communications, vol. 351, no. 3, pp. 733-738, 2006.

[37] L. Ravaux, C. Denoyelle, C. Monne, I. Limon, M. Raymondjean, and K. El Hadri, "Inhibition of interleukin-1 $\beta$ induced group IIA secretory phospholipase A2 expression by peroxisome proliferator-activated receptors (PPARs) in rat vascular smooth muscle cells: cooperation between PPAR $\beta$ and the proto-oncogene BCL-6," Molecular and Cellular Biology, vol. 27, no. 23, pp. 8374-8387, 2007.

[38] P. H. Villard, S. Caverni, A. Baanannou, et al., "PPAR $\alpha$ transcriptionally induces AhR expression in Caco-2, but represses AhR pro-inflammatory effects," Biochemical and Biophysical Research Communications, vol. 364, no. 4, pp. 896-901, 2007.

[39] N. A. Ignatenko, N. Babbar, D. Mehta, R. A. Casero Jr., and E. W. Gerner, "Suppression of polyamine catabolism by activated Ki-ras in human colon cancer cells," Molecular Carcinogenesis, vol. 39, no. 2, pp. 91-102, 2004.

[40] F. Zandbergen, S. Mandard, P. Escher, et al., "The $\mathrm{G}_{0} / \mathrm{G}_{1}$ switch gene 2 is a novel PPAR target gene," Biochemical Journal, vol. 392, no. 2, pp. 313-324, 2005.

[41] L. L. H. Peeters, J.-L. Vigne, M. K. Tee, D. Zhao, L. L. Waite, and R. N. Taylor, "PPAR $\gamma$ represses VEGF expression in human endometrial cells: implications for uterine angiogenesis," Angiogenesis, vol. 8, no. 4, pp. 373-379, 2006.

[42] T. Degenhardt, M. Matilainen, K.-H. Herzig, T. W. Dunlop, and C. Carlberg, "The insulin-like growth factor-binding protein 1 gene is a primary target of peroxisome proliferatoractivated receptors," The Journal of Biological Chemistry, vol. 281, no. 51, pp. 39607-39619, 2006.

[43] E. Sérée, P.-H. Villard, J.-M. Pascussi, et al., "Evidence for a new human CYP1A1 regulation pathway involving PPAR- $\alpha$ and 2 PPRE sites," Gastroenterology, vol. 127, no. 5, pp. 14361445, 2004.

[44] E. Y. Park, I. J. Cho, and S. G. Kim, "Transactivation of the PPAR-responsive enhancer module in chemopreventive glutathione $S$-transferase gene by the peroxisome proliferatoractivated receptor- $\gamma$ and retinoid X receptor heterodimer," Cancer Research, vol. 64, no. 10, pp. 3701-3713, 2004.

[45] J. Pandhare, S. K. Cooper, and J. M. Phang, "Proline oxidase, a proapoptotic gene, is induced by troglitazone: evidence for both peroxisome proliferator-activated receptor $\gamma$-dependent and -independent mechanisms," The Journal of Biological Chemistry, vol. 281, no. 4, pp. 2044-2052, 2006.

[46] L. Billiet, C. Furman, G. Larigauderie, et al., "Enhanced VDUP-1 gene expression by PPAR $\gamma$ agonist induces apoptosis in human macrophage," Journal of Cellular Physiology, vol. 214, no. 1, pp. 183-191, 2008.

[47] A. Boulanger, P. McLemore, N. G. Copeland, et al., "Identification of beta-carotene $15,15^{\prime}$-monooxygenase as a peroxisome proliferator-activated receptor target gene," The FASEB Journal, vol. 17, no. 10, pp. 1304-1306, 2003.

[48] J. F. Landrier, C. Thomas, J. Grober, et al., "The gene encoding the human ileal bile acid-binding protein (I-BABP) is regulated by peroxisome proliferator-activated receptors," Biochimica et Biophysica Acta, vol. 1735, no. 1, pp. 41-49, 2005.

[49] E. Efrati, J. Arsentiev-Rozenfeld, and I. Zelikovic, "The human paracellin-1 gene ( $h P C L N-1)$ : renal epithelial cellspecific expression and regulation," American Journal of Physiology, vol. 288, no. 2, pp. F272-F283, 2005.

[50] M. Sastre, I. Dewachter, S. Rossner, et al., "Nonsteroidal anti-inflammatory drugs repress $\beta$-secretase gene promoter activity by the activation of PPAR $\gamma$," Proceedings of the National Academy of Sciences of the United States of America, vol. 103, no. 2, pp. 443-448, 2006.

[51] A. Benigni, C. Zoja, S. Tomasoni, et al., "Transcriptional regulation of nephrin gene by peroxisome proliferatoractivated receptor- $\gamma$ agonist: molecular mechanism of the antiproteinuric effect of pioglitazone," Journal of the American Society of Nephrology, vol. 17, no. 6, pp. 1624-1632, 2006. 
[52] N. Viswakarma, S. Yu, S. Naik, et al., "Transcriptional regulation of Cidea, mitochondrial cell death-inducing DNA fragmentation factor $\alpha$-like effector $\mathrm{A}$, in mouse liver by peroxisome proliferator-activated receptor $\alpha$ and $\gamma$," The Journal of Biological Chemistry, vol. 282, no. 25, pp. 1861318624, 2007.

[53] T. Shimada, Y. Fujii, T. Koike, et al., "Peroxisome proliferatoractivated receptor $\gamma(\operatorname{PPAR} \gamma)$ regulates trefoil factor family 2 (TFF2) expression in gastric epithelial cells," The International Journal of Biochemistry \& Cell Biology, vol. 39, no. 3, pp. 626-637, 2007.

[54] A.-M. Krogsdam, C. A. F. Nielsen, S. Neve, et al., "Nuclear receptor corepressor-dependent repression of peroxisomeproliferator-activated receptor $\delta$-mediated transactivation," Biochemical Journal, vol. 363, no. 1, pp. 157-165, 2002.

[55] Y. Shi, M. Hon, and R. M. Evans, "The peroxisome proliferator-activated receptor $\delta$, an integrator of transcriptional repression and nuclear receptor signaling," Proceedings of the National Academy of Sciences of the United States of America, vol. 99, no. 5, pp. 2613-2618, 2002.

[56] L. H. Wang, X. Y. Yang, X. Zhang, et al., "Transcriptional inactivation of STAT3 by PPAR $\gamma$ suppresses IL-6-responsive multiple myeloma cells," Immunity, vol. 20, no. 2, pp. 205218, 2004.

[57] S. Ghisletti, W. Huang, S. Ogawa, et al., "Parallel SUMOylation-dependent pathways mediate gene- and signal-specific transrepression by LXRs and PPAR $\gamma$," Molecular Cell, vol. 25, no. 1, pp. 57-70, 2007.

[58] C.-H. Lee, A. Chawla, N. Urbiztondo, D. Liao, W. A. Boisvert, and R. M. Evans, "Transcriptional repression of atherogenic inflammation: modulation by PPAR $\delta$," Science, vol. 302, no. 5644, pp. 453-457, 2003.

[59] P. Delerive, J.-C. Fruchart, and B. Staels, "Peroxisome proliferator-activated receptors in inflammation control," Journal of Endocrinology, vol. 169, no. 3, pp. 453-459, 2001.

[60] T. M. Willson and W. Wahli, "Peroxisome proliferatoractivated receptor agonists," Current Opinion in Chemical Biology, vol. 1, no. 2, pp. 235-241, 1997.

[61] W. Ahmed, O. Ziouzenkova, J. Brown, et al., "PPARs and their metabolic modulation: new mechanisms for transcriptional regulation?" Journal of Internal Medicine, vol. 262, no. 2, pp. 184-198, 2007.

[62] G. Krey, O. Braissant, F. L'Horset, et al., "Fatty acids, eicosanoids, and hypolipidemic agents identified as ligands of peroxisome proliferator-activated receptors by coactivator-dependent receptor ligand assay," Molecular Endocrinology, vol. 11, no. 6, pp. 779-791, 1997.

[63] S. A. Kliewer, S. S. Sundseth, S. A. Jones, et al., "Fatty acids and eicosanoids regulate gene expression through direct interactions with peroxisome proliferator-activated receptors $\alpha$ and $\gamma$," Proceedings of the National Academy of Sciences of the United States of America, vol. 94, no. 9, pp. 4318-4323, 1997.

[64] B. M. Forman, J. Chen, and R. M. Evans, "Hypolipidemic drugs, polyunsaturated fatty acids, and eicosanoids are ligands for peroxisome proliferator-activated receptors $\alpha$ and $\delta$," Proceedings of the National Academy of Sciences of the United States of America, vol. 94, no. 9, pp. 4312-4317, 1997.

[65] P. R. Devchand, H. Keller, J. M. Peters, M. Vazquez, F. J. Gonzalez, and W. Wahli, "The PPAR $\alpha$-leukotriene $\mathrm{B}_{4}$ pathway to inflammation control," Nature, vol. 384, no. 6604, pp. 39-43, 1996.

[66] S. Sethi, O. Ziouzenkova, H. Ni, D. D. Wagner, J. Plutzky, and T. N. Mayadas, "Oxidized omega-3 fatty acids in fish oil inhibit leukocyte-endothelial interactions through activation of PPAR $\alpha$," Blood, vol. 100, no. 4, pp. 1340-1346, 2002.

[67] S. Theocharis, A. Margeli, P. Vielh, and G. Kouraklis, "Peroxisome proliferator-activated receptor- $\gamma$ ligands as cellcycle modulators," Cancer Treatment Reviews, vol. 30, no. 6, pp. 545-554, 2004.

[68] S. A. Kliewer, J. M. Lenhard, T. M. Willson, I. Patel, D. C. Morris, and J. M. Lehmann, "A prostaglandin $\mathrm{J}_{2}$ metabolite binds peroxisome proliferator-activated receptor $\gamma$ and promotes adipocyte differentiation," Cell, vol. 83, no. 5, pp. 813-819, 1995.

[69] C. M. Komar, "Peroxisome proliferator-activated receptors (PPARs) and ovarian function-implications for regulating steroidogenesis, differentiation, and tissue remodeling," Reproductive Biology and Endocrinology, vol. 3, article 41, 2005.

[70] J. D. Brown and J. Plutzky, "Peroxisome proliferatoractivated receptors as transcriptional nodal points and therapeutic targets," Circulation, vol. 115, no. 4, pp. 518-533, 2007.

[71] B. M. Forman, J. Chen, and R. M. Evans, "The peroxisome proliferator-activated receptors: ligands and activators," Annals of the New York Academy of Sciences, vol. 804, pp. 266-275, 1996.

[72] B. Staels and J.-C. Fruchart, "Therapeutic roles of peroxisome proliferator-activated receptor agonists," Diabetes, vol. 54, no. 8, pp. 2460-2470, 2005.

[73] J. M. Lehmann, L. B. Moore, T. A. Smith-Oliver, W. O. Wilkison, T. M. Willson, and S. A. Kliewer, "An antidiabetic thiazolidinedione is a high affinity ligand for peroxisome proliferator-activated receptor $\gamma(\operatorname{PPAR} \gamma)$," The Journal of Biological Chemistry, vol. 270, no. 22, pp. 12953-12956, 1995.

[74] M. Lehrke and M. A. Lazar, "The many faces of PPAR $y$," Cell, vol. 123, no. 6, pp. 993-999, 2005.

[75] J. M. Lehmann, J. M. Lenhard, B. B. Oliver, G. M. Ringold, and S. A. Kliewer, "Peroxisome proliferator-activated receptors $\alpha$ and $\gamma$ are activated by indomethacin and other nonsteroidal anti-inflammatory drugs," The Journal of Biological Chemistry, vol. 272, no. 6, pp. 3406-3410, 1997.

[76] D. J. A. Adamson, D. Frew, R. Tatoud, C. R. Wolf, and C. N. A. Palmer, "Diclofenac antagonizes peroxisome proliferatoractivated receptor- $\gamma$ signaling," Molecular Pharmacology, vol. 61, no. 1, pp. 7-12, 2002.

[77] M. D. Leibowitz, C. Fiévet, N. Hennuyer, et al., "Activation of $\operatorname{PPAR} \delta$ alters lipid metabolism in $\mathrm{db} / \mathrm{db}$ mice," FEBS Letters, vol. 473, no. 3, pp. 333-336, 2000.

[78] W. R. Oliver Jr., J. L. Shenk, M. R. Snaith, et al., "A selective peroxisome proliferator-activated receptor $\delta$ agonist promotes reverse cholesterol transport," Proceedings of the National Academy of Sciences of the United States of America, vol. 98, no. 9, pp. 5306-5311, 2001.

[79] T.-C. He, T. A. Chan, B. Vogelstein, and K. W. Kinzler, "PPAR $\delta$ is an APC-regulated target of nonsteroidal antiinflammatory drugs," Cell, vol. 99, no. 3, pp. 335-345, 1999.

[80] L. Xu, C. Han, and T. Wu, "A novel positive feedback loop between peroxisome proliferator-activated receptor$\delta$ and prostaglandin $\mathrm{E}_{2}$ signaling pathways for human cholangiocarcinoma cell growth," The Journal of Biological Chemistry, vol. 281, no. 45, pp. 33982-33996, 2006.

[81] M. W. Matthiessen, G. Pedersen, T. Albrektsen, S. Adamsen, J. Fleckner, and J. Brynskov, "Peroxisome proliferator-activated receptor expression and activation in normal human colonic epithelial cells and tubular adenomas," Scandinavian Journal of Gastroenterology, vol. 40, no. 2, pp. 198-205, 2005. 
[82] K. Fukumoto, Y. Yano, N. Virgona, et al., "Peroxisome proliferator-activated receptor $\delta$ as a molecular target to regulate lung cancer cell growth," FEBS Letters, vol. 579, no. 17, pp. 3829-3836, 2005.

[83] F. Y. Ali, K. Egan, G. A. FitzGerald, et al., "Role of prostacyclin versus peroxisome proliferator-activated receptor $\beta$ receptors in prostacyclin sensing by lung fibroblasts," American Journal of Respiratory Cell and Molecular Biology, vol. 34, no. 2, pp. 242-246, 2006.

[84] A. Planavila, R. Rodríguez-Calvo, M. Jové, et al., "Peroxisome proliferator-activated receptor $\beta / \delta$ activation inhibits hypertrophy in neonatal rat cardiomyocytes," Cardiovascular Research, vol. 65, no. 4, pp. 832-841, 2005.

[85] G. Martinasso, M. Maggiora, A. Trombetta, R. A. Canuto, and G. Muzio, "Effects of di(2-ethylhexyl) phthalate, a widely used peroxisome proliferator and plasticizer, on cell growth in the human keratino cyte cell line NCTC 2544," Journal of Toxicology and Environmental Health, Part A, vol. 69, no. 5, pp. 353-365, 2006.

[86] M. Westergaard, J. Henningsen, M. L. Svendsen, et al., "Modulation of keratinocyte gene expression and differentiation by PPAR-selective ligands and tetradecylthioacetic acid," Journal of Investigative Dermatology, vol. 116, no. 5, pp. 702-712, 2001.

[87] D. J. Kim, M. T. Bility, A. N. Billin, T. M. Willson, F. J. Gonzalez, and J. M. Peters, "PPAR $\beta / \delta$ selectively induces differentiation and inhibits cell proliferation," Cell Death \& Differentiation, vol. 13, no. 1, pp. 53-60, 2006.

[88] A. Nilsson, A. K. Ostlund Farrants, J. M. Nesland, H. S. Finstad, and J. I. Pedersen, "Potentiating effects of clofibric acid on the differentiation of HL-60 human promyelocytic leukemia cells induced by retinoids," European Journal of Cell Biology, vol. 67, no. 4, pp. 379-385, 1995.

[89] K. Hanley, Y. Jiang, S. S. He, et al., "Keratinocyte differentiation is stimulated by activators of the nuclear hormone receptor PPAR $\alpha$," Journal of Investigative Dermatology, vol. 110, no. 4, pp. 368-375, 1998.

[90] M. Bronfman, C. Ponce, S. Rojas, et al., "Enhanced differentiation of HL-60 leukemia cells to macrophages induced by ciprofibrate," European Journal of Cell Biology, vol. 77, no. 3, pp. 214-219, 1998.

[91] R. Scatena, G. Nocca, P. D. Sole, et al., "Bezafibrate as differentiating factor of human myeloid leukemia cells," Cell Death \& Differentiation, vol. 6, no. 8, pp. 781-787, 1999.

[92] G. D. Demetri, C. D. M. Fletcher, E. Mueller, et al., "Induction of solid tumor differentiation by the peroxisome proliferatoractivated receptor $\gamma$ ligand troglitazone in patients with liposarcoma," Proceedings of the National Academy of Sciences of the United States of America, vol. 96, no. 7, pp. 3951-3956, 1999.

[93] E. Mueller, P. Sarraf, P. Tontonoz, et al., "Terminal differentiation of human breast cancer through PPAR $\gamma$," Molecular Cell, vol. 1, no. 3, pp. 465-470, 1998.

[94] S. Pizzimenti, S. Laurora, F. Briatore, C. Ferretti, M. U. Dianzani, and G. Barrera, "Synergistic effect of 4-hydroxynonenal and PPAR ligands in controlling human leukemic cell growth and differentiation," Free Radical Biology and Medicine, vol. 32, no. 3, pp. 233-245, 2002.

[95] M. Schmuth, C. M. Haqq, W. J. Cairns, et al., "Peroxisome proliferator-activated receptor (PPAR)- $\beta / \delta$ stimulates differentiation and lipid accumulation in keratinocytes," Journal of Investigative Dermatology, vol. 122, no. 4, pp. 971-983, 2004.
[96] N. S. Tan, L. Michalik, N. Noy, et al., "Critical roles of $\mathrm{PPAR} \beta / \delta$ in keratinocyte response to inflammation," Genes \& Development, vol. 15, no. 24, pp. 3263-3277, 2001.

[97] C. S. Aung, H. M. Faddy, E. J. Lister, G. R. Monteith, and S. J. Roberts-Thomson, "Isoform specific changes in $\operatorname{PPAR} \alpha$ and $\beta$ in colon and breast cancer with differentiation," Biochemical and Biophysical Research Communications, vol. 340, no. 2, pp. 656-660, 2006.

[98] H. Vosper, L. Patel, T. L. Graham, et al., "The peroxisome proliferator-activated receptor $\delta$ promotes lipid accumulation in human macrophages," The Journal of Biological Chemistry, vol. 276, no. 47, pp. 44258-44265, 2001.

[99] I. Saluja, J. G. Granneman, and R. P. Skoff, "PPAR $\delta$ agonists stimulate oligodendrocyte differentiation in tissue culture," Glia, vol. 33, no. 3, pp. 191-204, 2001.

[100] S. Laurora, S. Pizzimenti, F. Briatore, et al., "Peroxisome proliferator-activated receptor ligands affect growth-related gene expression in human leukemic cells," Journal of Pharmacology and Experimental Therapeutics, vol. 305, no. 3, pp. 932-942, 2003.

[101] L. Fajas, M.-B. Debril, and J. Auwerx, "Peroxisome proliferator-activated receptor- $\gamma$ : from adipogenesis to carcinogenesis," Journal of Molecular Endocrinology, vol. 27, no. 1, pp. 1-9, 2001.

[102] H. Asou, W. Verbeek, E. Williamson, et al., "Growth inhibition of myeloid leukaemia cells by troglitazone, a ligand for peroxisome proliferator activated receptor gamma, and retinoids," International Journal of Oncology, vol. 15, no. 5, pp. 1027-1031, 1999.

[103] F. Yin, S. Wakino, Z. Liu, et al., "Troglitazone inhibits growth of MCF-7 breast carcinoma cells by targeting G1 cell cycle regulators," Biochemical and Biophysical Research Communications, vol. 286, no. 5, pp. 916-922, 2001.

[104] R. F. Morrison and S. R. Farmer, "Role of PPAR $\gamma$ in regulating a cascade expression of cyclin-dependent kinase inhibitors, p18(INK4c) and p21(Waf1/Cip1), during adipogenesis," The Journal of Biological Chemistry, vol. 274, no. 24, pp. 17088 17097, 1999.

[105] C. Giacinti and A. Giordano, "RB and cell cycle progression," Oncogene, vol. 25, no. 38, pp. 5220-5227, 2006.

[106] S. Wakino, U. Kintscher, S. Kim, F. Yin, W. A. Hsueh, and R. E. Law, "Peroxisome proliferator-activated receptor $\gamma$ ligands inhibit retinoblastoma phosphorylation and $\mathrm{G}_{1} \rightarrow \mathrm{S}$ transition in vascular smooth muscle cells," The Journal of Biological Chemistry, vol. 275, no. 29, pp. 22435-22441, 2000.

[107] S. T. de Dios, D. Bruemmer, R. J. Dilley, et al., "Inhibitory activity of clinical thiazolidinedione peroxisome proliferator activating receptor- $\gamma$ ligands toward internal mammary artery, radial artery, and saphenous vein smooth muscle cell proliferation," Circulation, vol. 107, no. 20, pp. 2548-2550, 2003.

[108] D. Bruemmer, J. P. Berger, J. Liu, et al., "A nonthiazolidinedione partial peroxisome proliferator-activated receptor $\gamma$ ligand inhibits vascular smooth muscle cell growth," European Journal of Pharmacology, vol. 466, no. 3, pp. 225-234, 2003.

[109] S. Kawa, T. Nikaido, H. Unno, N. Usuda, K. Nakayama, and K. Kiyosawa, "Growth inhibition and differentiation of pancreatic cancer cell lines by PPAR $\gamma$ ligand troglitazone," Pancreas, vol. 24, no. 1, pp. 1-7, 2002.

[110] A. D. Burdick, M. T. Bility, E. E. Girroir, et al., "Ligand activation of peroxisome proliferator-activated receptor$\beta / \delta(\operatorname{PPAR} \beta / \delta)$ inhibits cell growth of human N/TERT-1 
keratinocytes," Cellular Signalling, vol. 19, no. 6, pp. 1163 1171, 2007.

[111] F.-S. Chou, P.-S. Wang, S. Kulp, and J. J. Pinzone, "Effects of thiazolidinediones on differentiation, proliferation, and apoptosis," Molecular Cancer Research, vol. 5, no. 6, pp. 523530, 2007.

[112] Y. Kim, N. Suh, M. Sporn, and J. C. Reed, "An inducible pathway for degradation of FLIP protein sensitizes tumor cells to TRAIL-induced apoptosis," The Journal of Biological Chemistry, vol. 277, no. 25, pp. 22320-22329, 2002.

[113] T. Shimada, K. Kojima, K. Yoshiura, H. Hiraishi, and A. Terano, "Characteristics of the peroxisome proliferator activated receptor $\gamma(\operatorname{PPAR} \gamma)$ ligand induced apoptosis in colon cancer cells," Gut, vol. 50, no. 5, pp. 658-664, 2002.

[114] M. Toyoda, H. Takagi, N. Horiguchi, et al., "A ligand for peroxisome proliferator activated receptor $\gamma$ inhibits cell growth and induces apoptosis in human liver cancer cells," Gut, vol. 50, no. 4, pp. 563-567, 2002.

[115] E. Elstner, C. Müller, K. Koshizuka, et al., "Ligands for peroxisome proliferator-activated receptor $\gamma$ and retinoic acid receptor inhibit growth and induce apoptosis of human breast cancer cells in vitro and in BNX mice," Proceedings of the National Academy of Sciences of the United States of America, vol. 95, no. 15, pp. 8806-8811, 1998.

[116] C. E. Clay, G. Atsumi, K. P. High, and F. H. Chilton, "Early de novo gene expression is required for 15 -deoxy- $\Delta^{12,14}$ prostaglandin $\mathrm{J}_{2}$-induced apoptosis in breast cancer cells," The Journal of Biological Chemistry, vol. 276, no. 50, pp. 47131-47135, 2001.

[117] M. Kondo, T. Shibata, T. Kumagai, et al., "15-deoxy- $\Delta^{12,14}$ prostaglandin $\mathrm{J}_{2}$ : the endogenous electrophile that induces neuronal apoptosis," Proceedings of the National Academy of Sciences of the United States of America, vol. 99, no. 11, pp. 7367-7372, 2002.

[118] M. S. Lin, W. C. Chen, X. Bai, and Y. D. Wang, "Activation of peroxisome proliferator-activated receptor $\gamma$ inhibits cell growth via apoptosis and arrest of the cell cycle in human colorectal cancer," Journal of Digestive Diseases, vol. 8, no. 2, pp. 82-88, 2007.

[119] H. Liu, C. Zang, M. H. Fenner, et al., "Growth inhibition and apoptosis in human Philadelphia chromosome-positive lymphoblastic leukemia cell lines by treatment with the dual PPAR $\alpha / \gamma$ ligand TZD18," Blood, vol. 107, no. 9, pp. 36833692, 2006.

[120] G. Muzio, G. Martinasso, A. Trombetta, D. Di Simone, R. A. Canuto, and M. Maggiora, "HMG-CoA reductase and PPAR $\alpha$ are involved in clofibrate-induced apoptosis in human keratinocytes," Apoptosis, vol. 11, no. 2, pp. 265-275, 2006.

[121] T. Shigeto, Y. Yokoyama, B. Xin, and H. Mizunuma, "Peroxisome proliferator-activated receptor $\alpha$ and $\gamma$ ligands inhibit the growth of human ovarian cancer," Oncology Reports, vol. 18, no. 4, pp. 833-840, 2007.

[122] G. Muzio, M. Maggiora, M. Oraldi, A. Trombetta, and R. A. Canuto, "PPAR $\alpha$ and PP2A are involved in the proapoptotic effect of conjugated linoleic acid on human hepatoma cell line SK-HEP-1," International Journal of Cancer, vol. 121, no. 11, pp. 2395-2401, 2007.

[123] R. A. Gupta, D. Wang, S. Katkuri, H. Wang, S. K. Dey, and R. N. DuBois, "Activation of nuclear hormone receptor peroxisome proliferator-activated receptor- $\delta$ accelerates intestinal adenoma growth," Nature Medicine, vol. 10, no. 3, pp. 245$247,2004$.
[124] D. Wang, H. Wang, Q. Shi, et al., "Prostaglandin $E_{2}$ promotes colorectal adenoma growth via transactivation of the nuclear peroxisome proliferator-activated receptor $\delta$," Cancer Cell, vol. 6, no. 3, pp. 285-295, 2004.

[125] L. Michalik, B. Desvergne, N. S. Tan, et al., "Impaired skin wound healing in peroxisome proliferator-activated receptor (PPAR) $\alpha$ and PPAR $\beta$ mutant mice," The Journal of Cell Biology, vol. 154, no. 4, pp. 799-814, 2001.

[126] J. M. Peters, S. S. T. Lee, W. Li, et al., "Growths, adipose, brain, and skin alterations resulting from targeted disruption of the mouse peroxisome proliferator-activated receptor $\beta(\delta)$," Molecular and Cellular Biology, vol. 20, no. 14, pp. 5119-5128, 2000.

[127] T. Hatae, M. Wada, C. Yokoyama, M. Shimonishi, and T. Tanabe, "Prostacyclin-dependent apoptosis mediated by PPAR $\delta$," The Journal of Biological Chemistry, vol. 276, no. 49, pp. 46260-46267, 2001.

[128] R. A. Gupta, J. A. Brockman, P. Sarraf, T. M. Willson, and R. N. DuBois, "Target genes of peroxisome proliferatoractivated receptor $\gamma$ in colorectal cancer cells," The Journal of Biological Chemistry, vol. 276, no. 32, pp. 29681-29687, 2001.

[129] S. Altiok, M. Xu, and B. M. Spiegelman, "PPAR $\gamma$ induces cell cycle withdrawal: inhibition of E2f/DP DNA-binding activity via down-regulation of PP2A," Genes \& Development, vol. 11, no. 15, pp. 1987-1998, 1997.

[130] H. P. Koeffler, "Peroxisome proliferator-activated receptor $\gamma$ and cancers," Clinical Cancer Research, vol. 9, no. 1, pp. 1-9, 2003.

[131] N. Yamakawa-Karakida, K. Sugita, T. Inukai, et al., "Ligand activation of peroxisome proliferator-activated receptor $\gamma$ induces apoptosis of leukemia cells by down-regulating the c-myc gene expression via blockade of the Tcf- 4 activity," Cell Death \& Differentiation, vol. 9, no. 5, pp. 513-526, 2002.

[132] A. Cerbone, C. Toaldo, S. Laurora, et al., "4-hydroxynonenal and PPAR $\gamma$ ligands affect proliferation, differentiation, and apoptosis in colon cancer cells," Free Radical Biology and Medicine, vol. 42, no. 11, pp. 1661-1670, 2007.

[133] F. Bozzo, C. Bocca, S. Colombatto, and A. Miglietta, "Antiproliferative effect of conjugated linoleic acid in caco2 cells: involvement of PPAR $\gamma$ and APC/ $\beta$-catenin pathways," Chemico-Biological Interactions, vol. 169, no. 2, pp. 110-121, 2007.

[134] N. Marui, T. Sakai, N. Hosokawa, et al., "N-myc suppression and cell cycle arrest at $\mathrm{G}_{1}$ phase by prostaglandins," FEBS Letters, vol. 270, no. 1-2, pp. 15-18, 1990.

[135] T. Okura, M. Nakamura, Y. Takata, S. Watanabe, Y. Kitami, and K. Hiwada, "Troglitazone induces apoptosis via the p53 and Gadd45 pathway in vascular smooth muscle cells," European Journal of Pharmacology, vol. 407, no. 3, pp. 227$235,2000$.

[136] S. S. Palakurthi, H. Aktas, L. M. Grubissich, R. M. Mortensen, and J. A. Halperin, "Anticancer effects of thiazolidinediones are independent of peroxisome proliferator-activated receptor $\gamma$ and mediated by inhibition of translation initiation," Cancer Research, vol. 61, no. 16, pp. 6213-6218, 2001.

[137] I. Gouni-Berthold, H. K. Berthold, A.-A. Weber, et al., "Troglitazone and rosiglitazone induce apoptosis of vascular smooth muscle cells through an extracellular signal-regulated kinase-independent pathway," NaunynSchmiedeberg's Archives of Pharmacology, vol. 363, no. 2, pp. 215-221, 2001.

[138] K. Takeda, T. Ichiki, T. Tokunou, N. Iino, and A. Takeshita, "15-deoxy- $\Delta^{12,14}$-prostaglandin $\mathrm{J}_{2}$ and thiazolidinediones activate MEK/ERK pathway through phosphatidylinositol 
3-kinase in vascular smooth muscle cells," The Journal of Biological Chemistry, vol. 276, no. 52, pp. 48950-48955, 2001.

[139] M.-A. Bae and B. J. Song, "Critical role of c-Jun N-terminal protein kinase activation in troglitazone-induced apoptosis of human HepG2 hepatoma cells," Molecular Pharmacology, vol. 63, no. 2, pp. 401-408, 2003.

[140] S. J. Baek, L. C. Wilson, L. C. Hsi, and T. E. Eling, "Troglitazone, a peroxisome proliferator-activated receptor $\gamma(\operatorname{PPAR} \gamma)$ ligand, selectively induces the early growth response-1 gene independently of PPAR $\gamma$. A novel mechanism for its antitumorigenic activity," The Journal of Biological Chemistry, vol. 278 , no. 8, pp. 5845-5853, 2003.

[141] W. Motomura, T. Okumura, N. Takahashi, T. Obara, and Y. Kohgo, "Activation of peroxisome proliferator-activated receptor $\gamma$ by troglitazone inhibits cell growth through the increase of p27 $7^{\mathrm{Kip} 1}$ in human pancreatic carcinoma cells," Cancer Research, vol. 60, no. 19, pp. 5558-5564, 2000.

[142] A. Sugimura, Y. Kiriyama, H. Nochi, et al., "Troglitazone suppresses cell growth of myeloid leukemia cell lines by induction of p21WAF1/CIP1 cyclin-dependent kinase inhibitor," Biochemical and Biophysical Research Communications, vol. 261, no. 3, pp. 833-837, 1999.

[143] C.-C. Yang, Y.-C. Wang, S. Wei, et al., "Peroxisome proliferator-activated receptor $\gamma$-independent suppression of androgen receptor expression by troglitazone mechanism and pharmacologic exploitation," Cancer Research, vol. 67, no. 7, pp. 3229-3238, 2007.

[144] G. He, Y. M. Sung, J. DiGiovanni, and S. M. Fischer, "Thiazolidinediones inhibit insulin-like growth factor-I-induced activation of p70S6 kinase and suppress insulin-like growth factor-I tumor-promoting activity," Cancer Research, vol. 66, no. 3, pp. 1873-1878, 2006.

[145] J.-W. Huang, C.-W. Shiau, Y.-T. Yang, et al., "Peroxisome proliferator-activated receptor $\gamma$-independent ablation of cyclin D1 by thiazolidinediones and their derivatives in breast cancer cells," Molecular Pharmacology, vol. 67, no. 4, pp. 1342-1348, 2005.

[146] K.-H. Kim, Y. S. Cho, J.-M. Park, S.-O. Yoon, K.-W. Kim, and A.-S. Chung, "Pro-MMP-2 activation by the PPAR $\gamma$ agonist, ciglitazone, induces cell invasion through the generation of ROS and the activation of ERK," FEBS Letters, vol. 581, no. 17, pp. 3303-3310, 2007.

[147] C. L. Chaffer, D. M. Thomas, E. W. Thompson, and E. D. Williams, "PPAR $\gamma$-independent induction of growth arrest and apoptosis in prostate and bladder carcinoma," $B M C$ Cancer, vol. 6, article 53, pp. 1-13, 2006.

[148] M. Takenokuchi, K. Saigo, Y. Nakamachi, et al., "Troglitazone inhibits cell growth and induces apoptosis of B-cell acute lymphoblastic leukemia cells with $\mathrm{t}(14 ; 18)$, , Acta Haematologica, vol. 116, no. 1, pp. 30-40, 2006.

[149] M. Lu, T. Kwan, C. Yu, et al., "Peroxisome proliferatoractivated receptor $\gamma$ agonists promote TRAIL-induced apoptosis by reducing survivin levels via cyclin D3 repression and cell cycle arrest," The Journal of Biological Chemistry, vol. 280, no. 8, pp. 6742-6751, 2005.

[150] G. He, P. Thuillier, and S. M. Fischer, "Troglitazone inhibits cyclin D1 expression and cell cycling independently of PPAR $\gamma$ in normal mouse skin keratinocytes," Journal of Investigative Dermatology, vol. 123, no. 6, pp. 1110-1119, 2004.

[151] R. Grau, M. A. Iñiguez, and M. Fresno, "Inhibition of activator protein 1 activation, vascular endothelial growth factor, and cyclooxygenase- 2 expression by 15 -deoxy- $\Delta^{12,14}$ prostaglandin $\mathrm{J}_{2}$ in colon carcinoma cells: evidence for a redox-sensitive peroxisome proliferator-activated receptor- $\gamma$-independent mechanism," Cancer Research, vol. 64, no. 15, pp. 5162-5171, 2004.

[152] D. M. Ray, F. Akbiyik, and R. P. Phipps, "The peroxisome proliferator-activated receptor $\gamma(\operatorname{PPAR} \gamma)$ ligands 15-deoxy$\Delta^{12,14}$-prostaglandin $\mathrm{J}_{2}$ and ciglitazone induce human $\mathrm{B}$ lymphocyte and B cell lymphoma apoptosis by $\operatorname{PPAR} \gamma$ independent mechanisms," The Journal of Immunology, vol. 177, no. 8, pp. 5068-5076, 2006.

[153] S. Nakata, T. Yoshida, T. Shiraishi, et al., "15-deoxy- $\Delta^{12,14}$ prostaglandin $\mathrm{J}_{2}$ induces death receptor 5 expression through mRNA stabilization independently of PPAR $y$ and potentiates TRAIL-induced apoptosis," Molecular Cancer Therapeutics, vol. 5, no. 7, pp. 1827-1835, 2006.

[154] Y. Ito, O. Yamanoshita, N. Asaeda, et al., "Di(2ethylhexyl)phthalate induces hepatic tumorigenesis through a peroxisome proliferator-activated receptor $\alpha$-independent pathway," Journal of Occupational Health, vol. 49, no. 3, pp. 172-182, 2007.

[155] R. Cunard, D. DiCampli, D. C. Archer, et al., "WY14,643, a $\operatorname{PPAR} \alpha$ ligand, has profound effects on immune responses in vivo," The Journal of Immunology, vol. 169, no. 12, pp. 68066812, 2002.

[156] S. Srivastava, D. J. Conklin, S.-Q. Liu, et al., "Identification of biochemical pathways for the metabolism of oxidized low-density lipoprotein derived aldehyde-4-hydroxy trans-2nonenal in vascular smooth muscle cells," Atherosclerosis, vol. 158, no. 2, pp. 339-350, 2001.

[157] M. U. Dianzani, "4-hydroxynonenal from pathology to physiology," Molecular Aspects of Medicine, vol. 24, no. 4-5, pp. 263-272, 2003.

[158] H. Esterbauer, R. J. Schaur, and H. Zollner, "Chemistry and biochemistry of 4-hydroxynonenal, malonaldehyde and related aldehydes," Free Radical Biology and Medicine, vol. 11, no. 1, pp. 81-128, 1991.

[159] K. Uchida, "4-hydroxy-2-nonenal: a product and mediator of oxidative stress," Progress in Lipid Research, vol. 42, no. 4, pp. 318-343, 2003.

[160] Y. C. Awasthi, G. A. S. Ansari, and S. Awasthi, "Regulation of 4-hydroxynonenal mediated signaling by glutathione Stransferases," Methods in Enzymology, vol. 401, pp. 379-407, 2005.

[161] Y. Yang, S. Sharma, A. Sharma, S. Awasthi, and Y. C. Awasthi, "Lipid peroxidation and cell cycle signaling: 4hydroxynonenal, a key molecule in stress mediated signalling," Acta Biochimica Polonica, vol. 50, no. 2, pp. 319-336, 2003.

[162] G. Barrera, C. Di Mauro, R. Muraca, et al., "Induction of differentiation in human HL-60 cells by 4-hydroxynonenal, a product of lipid peroxidation," Experimental Cell Research, vol. 197, no. 2, pp. 148-152, 1991.

[163] G. Barrera, S. Pizzimenti, R. Muraca, et al., "Effect of 4hydroxynonenal on cell cycle progression and expression of differentiation-associated antigens in HL-60 cells," Free Radical Biology and Medicine, vol. 20, no. 3, pp. 455-462, 1996.

[164] Y. C. Awasthi, R. Sharma, J. Z. Cheng, et al., "Role of 4-hydroxynonenal in stress-mediated apoptosis signalling," Molecular Aspects of Medicine, vol. 24, no. 4-5, pp. 219-230, 2003.

[165] S. Laurora, E. Tamagno, F. Briatore, et al., "4-hydroxynonenal modulation of p53 family gene expression in the SK-N-BE neuroblastoma cell line," Free Radical Biology and Medicine, vol. 38, no. 2, pp. 215-225, 2005. 
[166] S. Pizzimenti, G. Barrera, M. U. Dianzani, and S. Brüsselbach, "Inhibition of D1, D2, and A-cyclin expression in HL-60 cells by the lipid peroxydation product 4-hydroxynonenal," Free Radical Biology and Medicine, vol. 26, no. 11-12, pp. 15781586, 1999.

[167] G. Barrera, S. Pizzimenti, S. Laurora, E. Moroni, B. Giglioni, and M. U. Dianzani, "4-hydroxynonenal affects pRb/E2F pathway in HL-60 human leukemic cells," Biochemical and Biophysical Research Communications, vol. 295, no. 2, pp. 267-275, 2002.

[168] S. Pizzimenti, F. Briatore, S. Laurora, et al., "4hydroxynonenal inhibits telomerase activity and hTERT expression in human leukemic cell lines," Free Radical Biology and Medicine, vol. 40, no. 9, pp. 1578-1591, 2006.

[169] P. Tontonoz, L. Nagy, J. G. A. Alvarez, V. A. Thomaszy, and R. M. Evans, "PPAR- $\gamma$ promotes monocyte/magrophage differentiation and uptake of oxidized LDL," Cell, vol. 93, no. 2, pp. 241-452, 1998.

[170] S. A. Kliewer, J. M. Lenhard, T. M. Willson, I. Patel, D. C. Morris, and J. M. Lehmann, "A prostaglandin $\mathrm{J}_{2}$ metabolite binds peroxisome proliferator-activated receptor $\gamma$ and promotes adipocyte differentiation," Cell, vol. 83, no. 5, pp. 813-819, 1995.

[171] Y. Iwashima, M. Eto, S. Horiuchi, and H. Sano, "Advanced glycation end product-induced peroxisome proliferatoractivated receptor $\gamma$ gene expression in the cultured mesangial cells," Biochemical and Biophysical Research Communications, vol. 264, no. 2, pp. 441-448, 1999.

[172] M. Kondo, T. Oya-Ito, T. Kumagai, T. Osawa, and K. Uchida, "Cyclopentenone prostaglandins as potential inducers of intracellular oxidative stress," The Journal of Biological Chemistry, vol. 276, no. 15, pp. 12076-12083, 2001.

[173] A. V. Yeldandi, M. S. Rao, and J. K. Reddy, "Hydrogen peroxide generation in peroxisome proliferator-induced oncogenesis," Mutation Research, vol. 448, no. 2, pp. 159-177, 2000.

[174] G. Muzio, A. Trombetta, M. Maggiora, et al., "Arachidonic acid suppresses growth of human lung tumor A549 cells through down-regulation of ALDH3A1 expression," Free Radical Biology and Medicine, vol. 40, no. 11, pp. 1929-1938, 2006.

[175] J. D. Coleman, K. S. Prabhu, J. T. Thompson, et al., "The oxidative stress mediator 4-hydroxynonenal is an intracellular agonist of the nuclear receptor peroxisome proliferatoractivated receptor- $\beta / \delta(\operatorname{PPAR} \beta / \delta), "$ Free Radical Biology and Medicine, vol. 42, no. 8, pp. 1155-1164, 2007. 


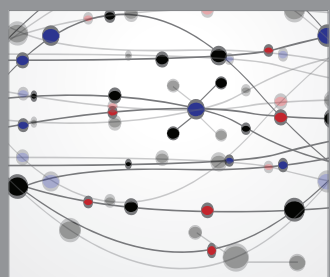

The Scientific World Journal
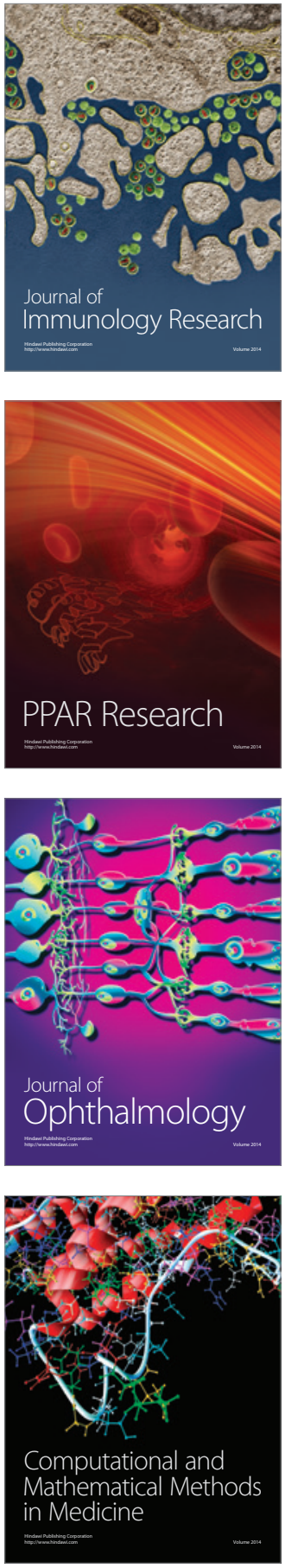

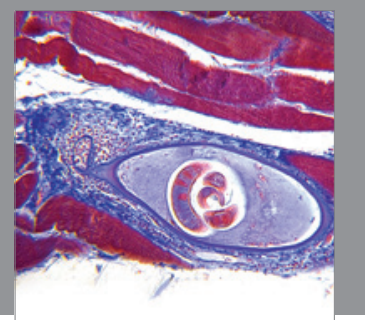

Gastroenterology

Research and Practice
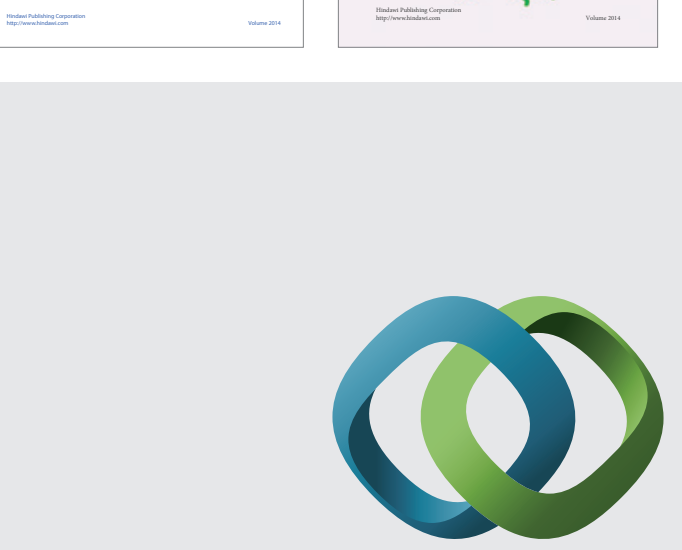

\section{Hindawi}

Submit your manuscripts at

http://www.hindawi.com
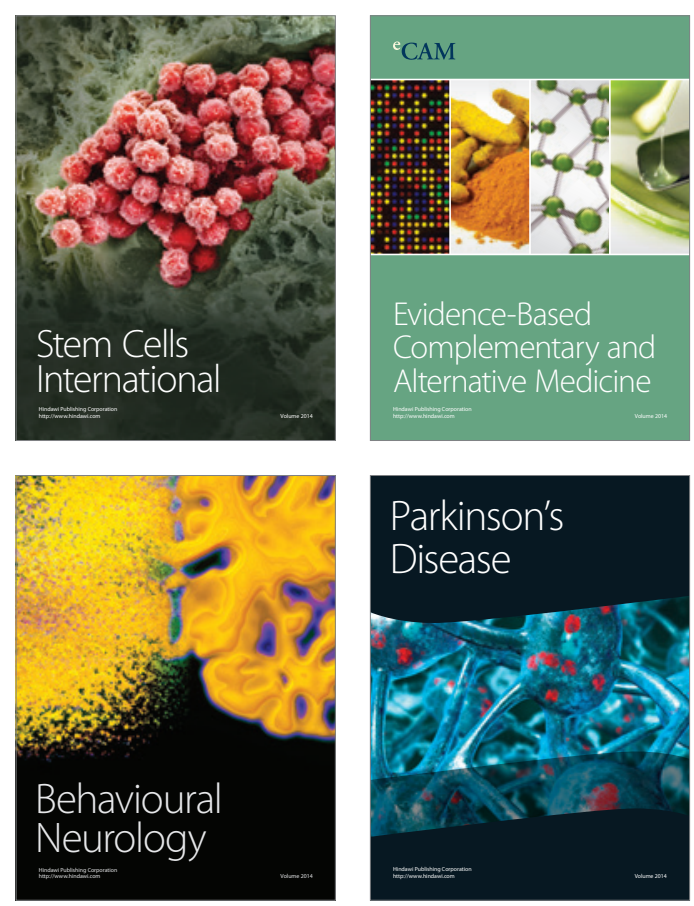

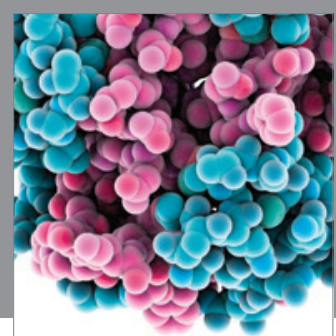

Journal of
Diabetes Research

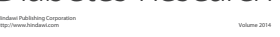

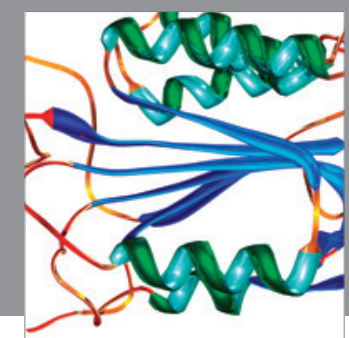

Disease Markers
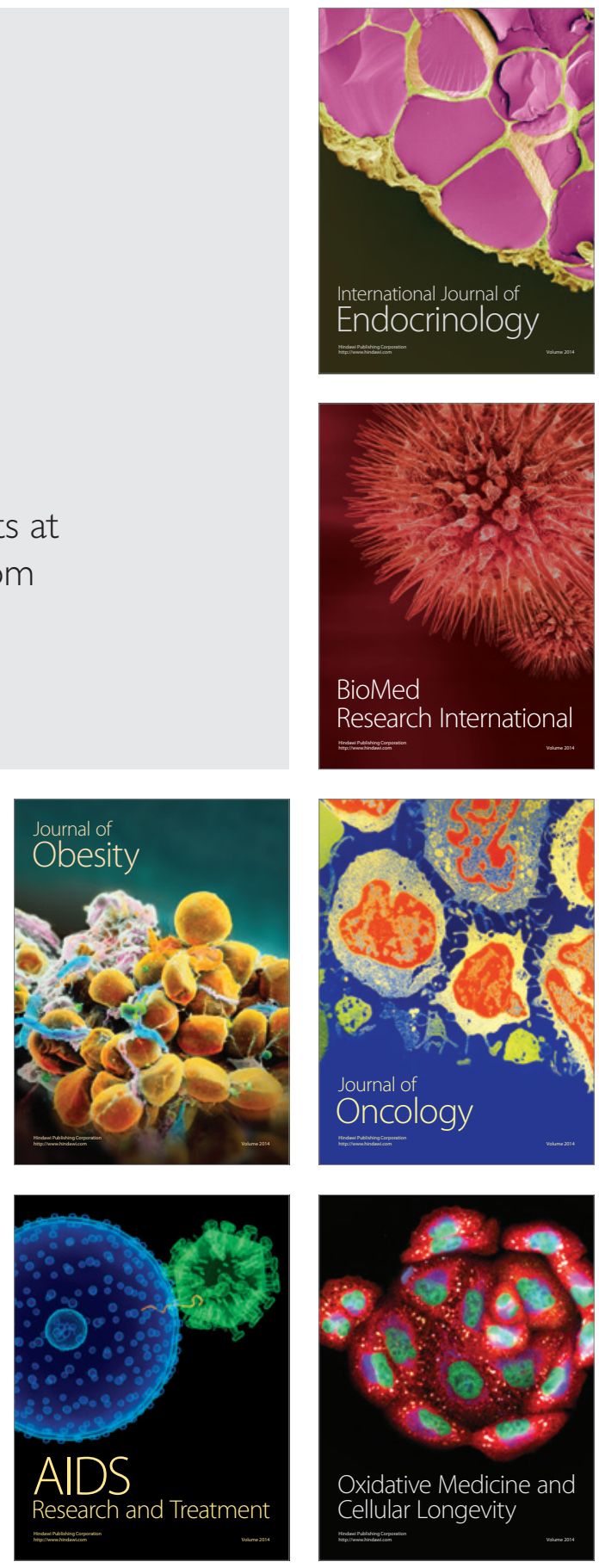